2. To: (Receiving órganization)

Distribution

5. Proj./Prog./Dept./Div.:

Spare Parts List

3. From: (originating organization)

6. Design Authority/ Design Agent/Cog. Engr.:

W. H. Hays

8. Originator Remarks:

Spare parts 1 ist for 241-C-106 waste retrieval

11. Receiver Remarks: 11A. Design Baseline Document? [] Yes [X] No

\section{3}

4. Related EDT No.:

$\mathrm{N} / \mathrm{A}$

7. Purchase Order No.:

$N / A$

9. Equip./Component No.:

$N / A$

10. System/Bldg./Facility:

241-C-106

12. Major Assin. Dwg. No,:

N/A

13. Permit/Permit Application No.: N/A

14. Required Response Date: N/A

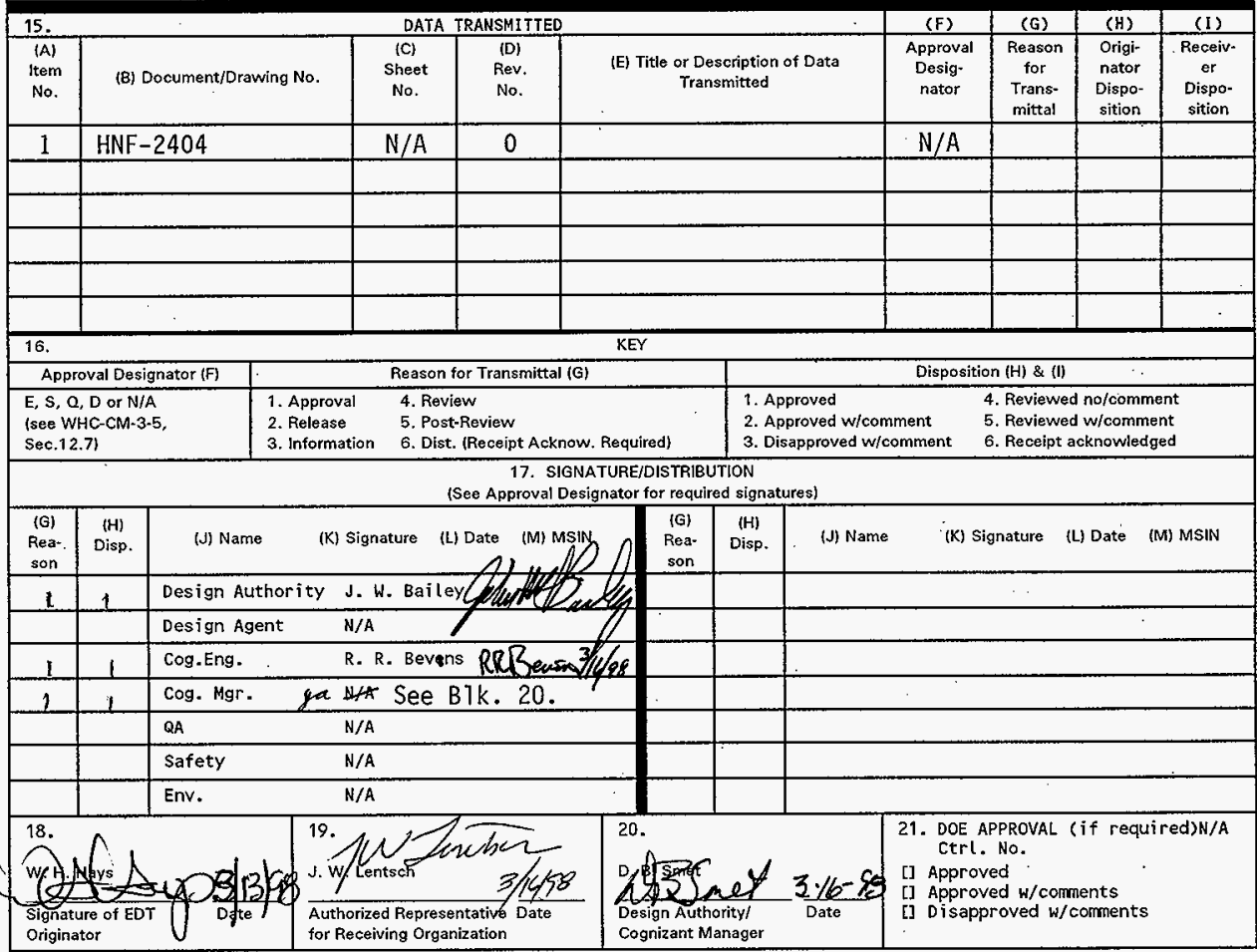




\title{
PROJECT W-320 241-C-106 WASTE RETRIEVAL SPARE PARTS LIST
}

\author{
H. H. Hays \\ Fluor Daniel Northwest, Inc., Richland, WA 99352 \\ U.S. Department of Energy Contract DE-ACO6-96RL13200 \\ $\begin{array}{lll}\text { EDT/ECN: } & 603743 & \text { UC: } 512 \\ \text { Org Code: } & \text { SFC21000 } & \text { Charge Code: } A 941101 \\ \text { B\&R Code: } & \text { EW3130010 } & \text { Total Pages: } 59\end{array}$ \\ Key Words: W-320; waste retrieval; spare parts; 241-C-106; AY Farm; \\ C Farm
}

Abstract: Spare parts for equipment installed in the tank dome space or pump or valve pits should not be inventoried onsite due to the extensive, time-consuming work package planning, personnel/equipment mobilization, and funding requirements that are prerequisites to any repair or replacement. These issues provide adequate time to procure parts from of site sources.

A11 parts 1isted in this inventory can either be stocked in the DynCorp Tri-Cities Services, Inc., 2101-M Warehouse, or are available from the vendor/manufacturer.

TRADEMARK DISCLAIMER. Reference herein to any specific conmercial product, process, or service by trade name, tradenark, manufacturer, or othervise, does not necessarily constitute or imply its endorsement, recommendation, or favoring by the United States Government or any agency thereof or its contractors or subcontractors.

Printed in the United States of America. To obtain copies of this document, contact: WHC/BCS Document Control Services, P.0. Box 1970, Mailstop H6-08, Richland UA 99352, Phone, (5092 372-2420. Fax (509) 376-4989.

$\frac{\text { Ranis Q Rapalal } 3-23-98}{\text { Date }}$

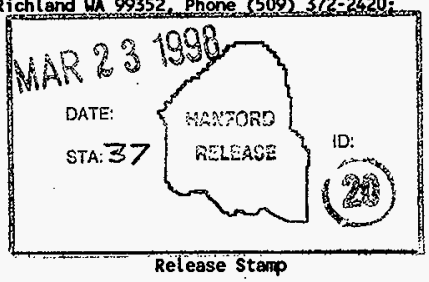

\section{Approved for Public Release}


HNF-2404

Revision 0

\section{March 1998}
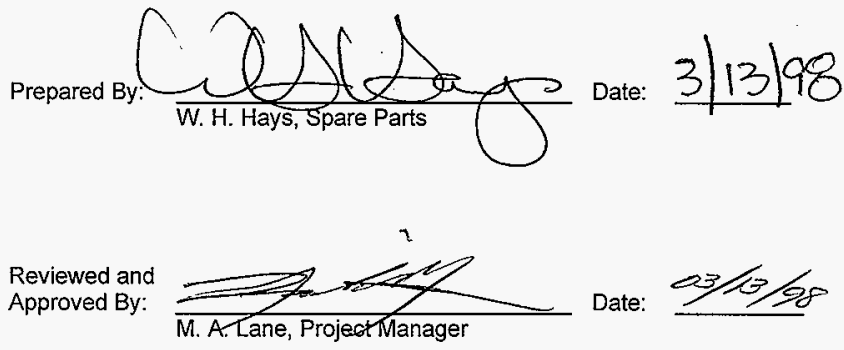

Prepared by

Fluor Daniel Northwest, Inc.

Richland, Washington

for

Lockheed Martin Hanford Corporation

Richland, Washington 


\section{C-106 W-320 WASTE REMOVAL PROJECT \\ W-320 SPARE PARTS}

Spare part listings have been developed using the following;

- Interim Safety Equipment list for 241-C-106 Waste Removal Project

- Vendor's recommended spare parts lists

- Fluor Daniel Northwest (FDNW) Design Engineer's recommended spare part lists

- Lockheed Martin Hanford Corporation (LMHC) Design Authority's recommendation(s)

- Market surveys of readily available spare parts

- Historical usage of similar parts/equipment

- LMHC Maintenance Concepts recommendations

- Construction field personnel knowledge and experience

- Assumptions of project scope and expected life.

\section{ASSUMPTION}

Spare parts for equipment installed in the tank dome space or pump or valve pits should not be inventoried onsite due to the extensive, time-consuming work package planning, personnel/equipment mobilization, and funding requirements that are prerequisites to any repair or replacement. These issues provide adequate time to procure parts from offsite sources.

Exceptions:

- If the part is a speciality item and not available from any vendor's inventory.

- If the item is already available as a construction spare or previous purchase.

- If the delivery time from an offsite source is counterproductive to the project schedule.

Spare parts located in other than intrusive locations should not be maintained onsite if they are available from a vendor's inventory and delivery can be accomplished in a reasonable amount of time (i.e., 5 to 10 working days).

Onsite inventories of spare parts have not been recommended for the following systems:

- C Farm Ventilation

- In-Tank Imaging System

- AY/C Farm Sluicing PumpNinch, Variable Speed Drive(s)

- C Farm Air Inlet Cooling

For these systems, we have recommended various methods for ensuring system reliability at minimal costs to the project. These methods consist of vendor agreements wherein the vendor will maintain spares at their facility; service agreements will ensure that spares and service technicians are available to support project schedules; vendors certification(s) that spares are readily available for the duration of the project and costs incurred only when delivered to the site; engineering solutions to power/ventilation loss during the pumping phase of the project.

These options are further defined within the spares listing under the specific system affected by this approach.

Numerous fuses, indicator lights and bulbs should be maintained onsite to support C-106 sluicing operations, but not necessarily in an official spare parts inventory. We recommend that adequate quantities be maintained at the work location and controlled as shop consumables. These items have been identified in this listing.

All parts listed in this inventory can either be stocked in the DynCorp Tri-Cities Services, Inc., 2101-M Warehouse or are available from the vendor/manufacturer. 


\section{W-320-C-106 WASTE RETRIEVAL PROJECT SPARE PARTS}

Spare parts are categorized by major system, equipment piece, and component.

\begin{tabular}{|l|}
\hline \multicolumn{1}{|c|}{ SYSTEM } \\
\hline Cathodic Protection \\
\hline AY Farm Electrical Distribution \\
\hline AY Farm Equipment and Instrumentation \\
\hline AY Farm Sluicing Pump Winch \\
\hline AY Farm 02-E Pit Cooling \\
\hline AY 102 Ventilation \\
\hline \multicolumn{1}{|c|}{ Annulus } \\
\hline Primary \\
\hline C Farm Electrical Distribution \\
\hline C Farm Equipment and Instrumentation \\
\hline C Farm Process Air \\
\hline C Farm Slurry Pump/Winch \\
\hline C Farm Sluicer \\
\hline C Farm In-Tank Image System \\
\hline C Farm Air Inlet Cooling \\
\hline Portable Exhauster \\
\hline
\end{tabular}


SPARE PARTS FOR W-320 PROJECT

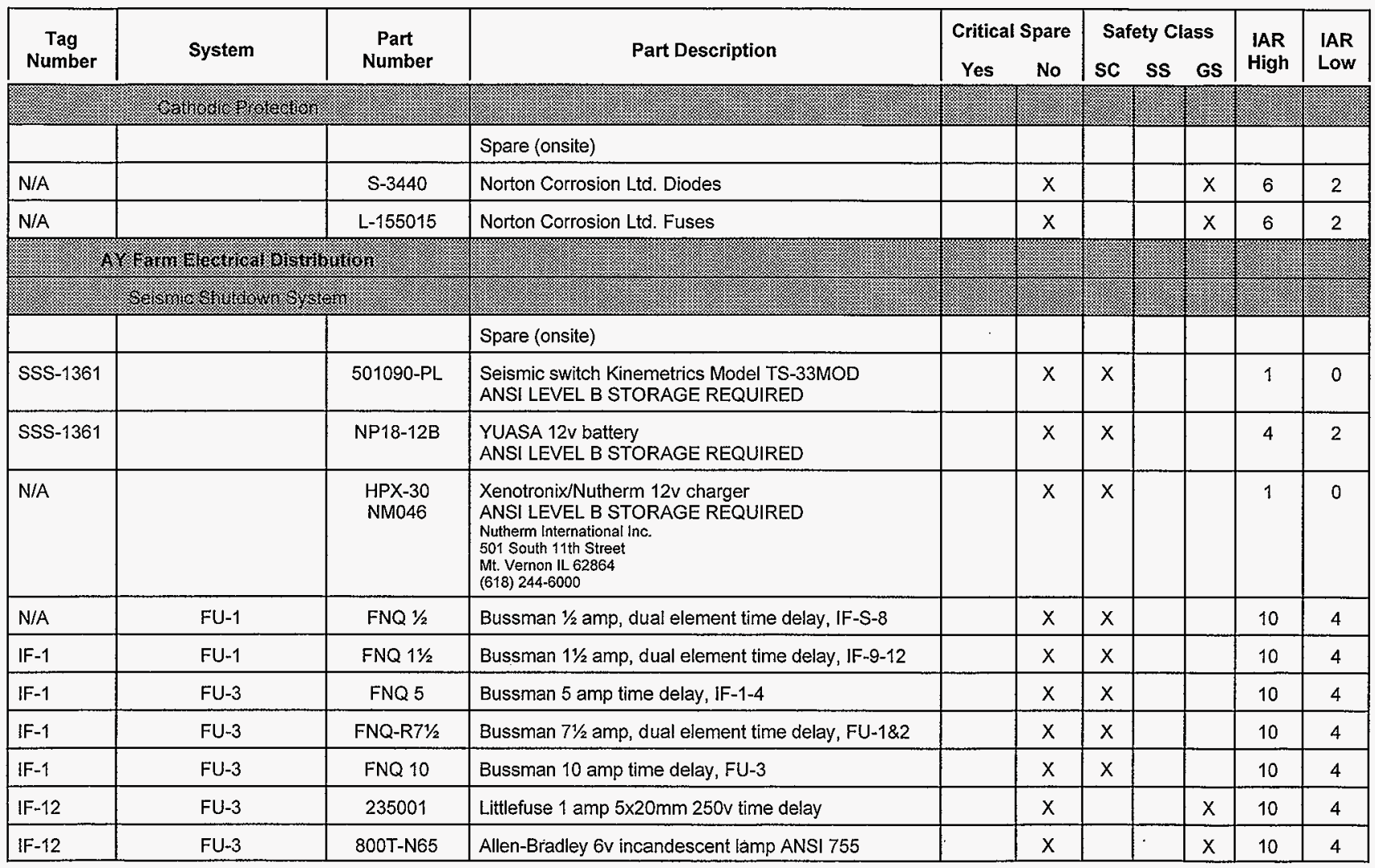




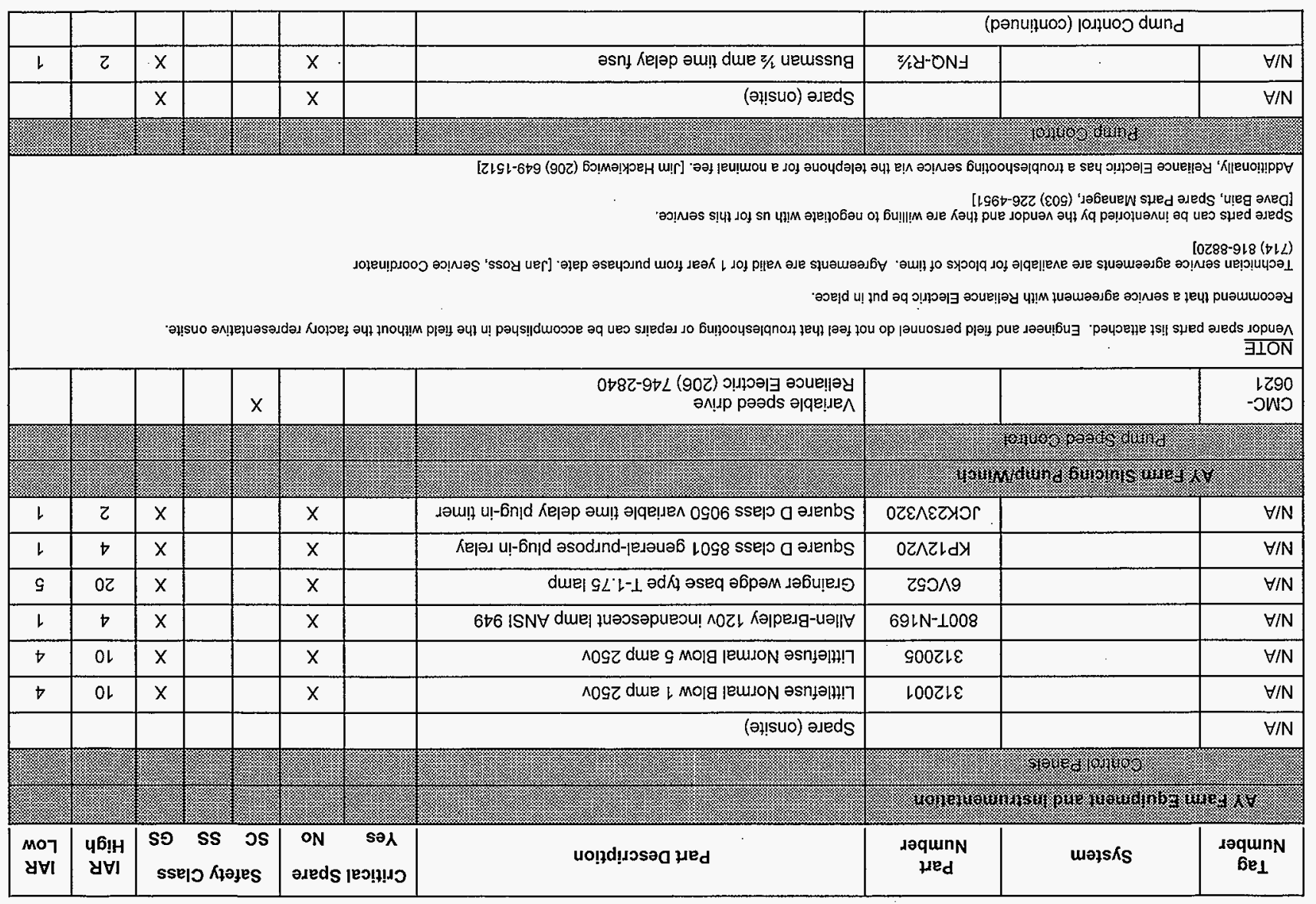

\section{0 ^}


HNF-2404, Rev. 0

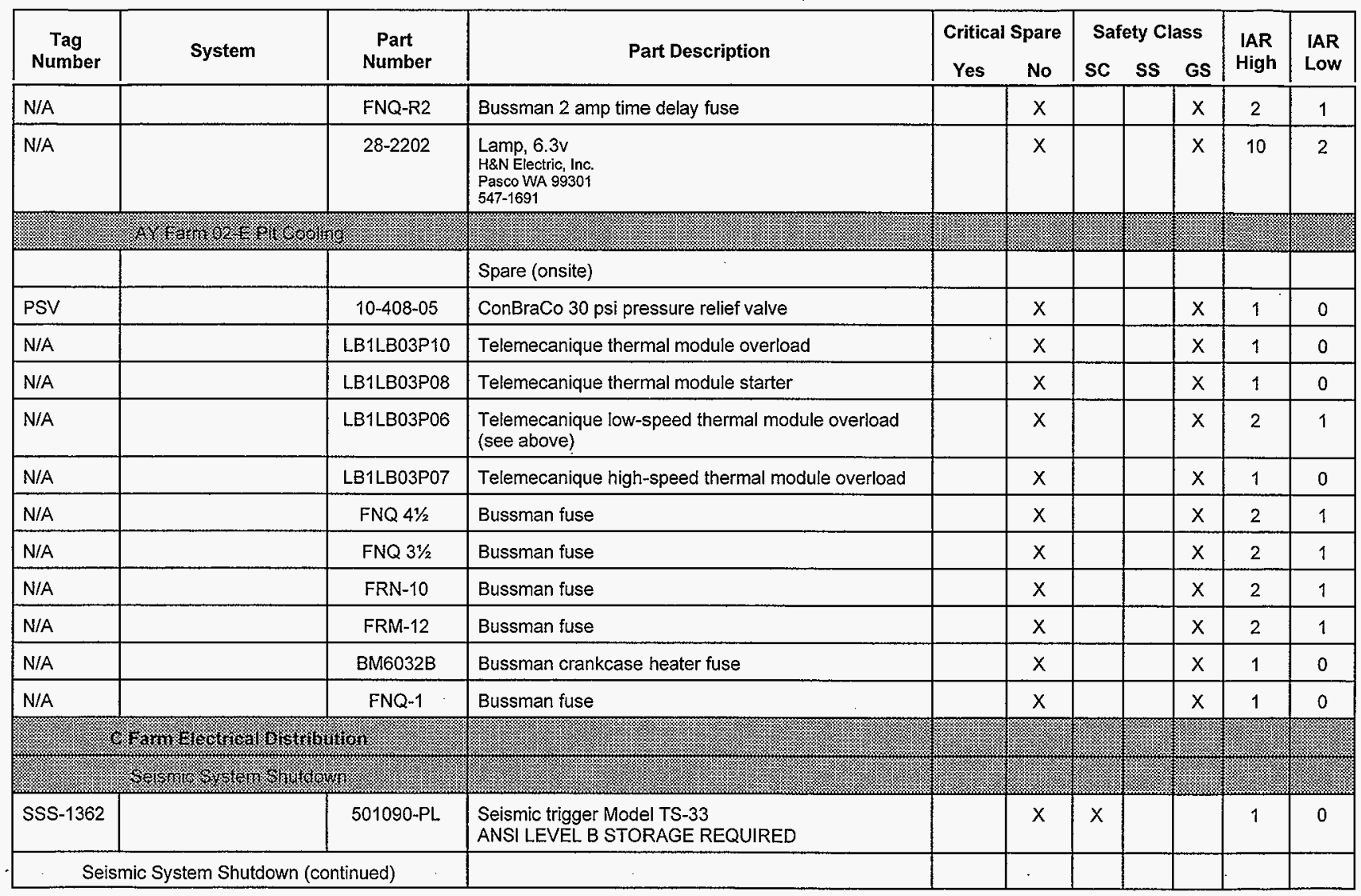


HNF-2404, Rev. 0

\begin{tabular}{|c|c|c|c|c|c|c|c|c|c|c|}
\hline $\begin{array}{c}\text { Tag } \\
\text { Number }\end{array}$ & System & $\begin{array}{l}\text { Part } \\
\text { Number }\end{array}$ & Part Description & $\begin{array}{c}\text { Critic } \\
\text { Yes }\end{array}$ & $\begin{array}{l}\text { pare } \\
\text { No }\end{array}$ & & $\begin{array}{l}\text { ty } \mathrm{Cl} \\
\text { Ss }\end{array}$ & $\begin{array}{l}\text { ass } \\
\text { GS }\end{array}$ & $\begin{array}{l}\text { IAR } \\
\text { High }\end{array}$ & $\begin{array}{l}\text { IAR } \\
\text { Low }\end{array}$ \\
\hline N/A & & NP18-12B & $\begin{array}{l}\text { YUASA } 12 v \text { battery } \\
\text { ANSI LEVEL B STORAGE REQUIRED }\end{array}$ & & $x$ & $x$ & & & 4 & 2 \\
\hline N/A & & $\begin{array}{l}\text { HPX-30 } \\
\text { NM046 }\end{array}$ & $\begin{array}{l}\text { Xenotronix/Nutherm } 12 v \text { charger } \\
\text { ANSI LEVEL B STORAGE REQUIRED } \\
\text { Nutherm International Inc. } \\
501 \text { South } 11 \text { th Street } \\
\text { Mt. Vernon IL } 62864 \\
\text { (618) 244-6000 }\end{array}$ & & $x$ & & & $x$ & 1 & \\
\hline$N / A$ & & FNQ $1 / 2$ & Bussman $1 / 2$ amp, dual element time delay & & $\mathrm{x}$ & $x$ & & & 10 & 4 \\
\hline N/A & & FNQ $11 / 2$ & Bussman $11 / 2$ amp, dual element time delay & & $\mathrm{x}$ & $\mathrm{x}$ & & & 10 & 4 \\
\hline N/A & & FNQ 5 & Bussman 5 amp time delay & & $\mathrm{x}$ & $\mathrm{x}$ & & & 10 & 4 \\
\hline N/A & & FNQ-R71/2 & Bussman $71 / 2$ amp, dual element time delay & & $x$ & $\mathrm{x}$ & & & 10 & 4 \\
\hline N/A & & FNQ 10 & Bussman 10 amp time delay & & $x$ & $x$ & & & 10 & 4 \\
\hline N/A & & 235001 & Littlefuse 1 amp $5 \times 20 \mathrm{~mm} 250 \mathrm{v}$ time delay & & $x$ & $\mathrm{x}$ & & & 10 & 4 \\
\hline $\mathrm{N} / \mathrm{A}$ & & $800 T-N 65$ & Allen-Bradley $6 \mathrm{v}$ incandescent lamp ANSI 755 & & $x$ & $x$ & & & 10 & 4 \\
\hline \multicolumn{11}{|c|}{ (3) } \\
\hline & (3. & (3. & (s) & & & $\sqrt{18}$ & & & 8 & \\
\hline & Exhaust stack & & Spare (onsite) & & & & & & & \\
\hline N/A & & $\mathrm{COHD} 73$ & Eberline fuse drawer (for power entry drawer) & & $x$ & & & $x$ & 1 & 0 \\
\hline$N / A$ & & COPR 13 & Fuse holder assembly & & $x$ & & & $x$ & 1 & 0 \\
\hline N/A & & FIFP10 & Filter paper & & $\mathrm{x}$ & & & $\mathrm{x}$ & 100 & 20 \\
\hline N/A & & FUSB 12 & $1 \mathrm{amp} 250 \mathrm{v}$ Slo Blo fuse $3 A \mathrm{G}$ & & $x$ & & & $x$ & 5 & 1 \\
\hline N/A & & MEVE 118 & 2.4 amp $12 \mathrm{v}$ power supply & & $x$ & & & $x$ & 1 & 0 \\
\hline RE-1363 & & SP24E & AMS-4 front panel board & & $x$ & & & $x$ & 1 & 0 \\
\hline
\end{tabular}


HNF-2404, Rev. 0

\begin{tabular}{|c|c|c|c|c|c|c|c|c|c|c|}
\hline \multirow{2}{*}{$\begin{array}{c}\text { Tag } \\
\text { Number }\end{array}$} & \multirow{2}{*}{ System } & \multirow{2}{*}{$\begin{array}{c}\text { Part } \\
\text { Number }\end{array}$} & \multirow{2}{*}{ Part Description } & \multicolumn{2}{|c|}{ Critical Spare } & \multicolumn{3}{|c|}{ Safety Class } & \multirow{2}{*}{$\begin{array}{l}\text { IAR } \\
\text { High }\end{array}$} & \multirow{2}{*}{$\begin{array}{l}\text { IAR } \\
\text { Low }\end{array}$} \\
\hline & & & & Yes & No & sc & ss & GS & & \\
\hline \multicolumn{11}{|c|}{ Exhaust Skid (continued } \\
\hline & $\begin{array}{c}\text { Exhaust Stack } \\
\text { (continued) }\end{array}$ & & & & & & & & & \\
\hline \multirow[t]{2}{*}{ RE-1363 } & & SP29-A & AMS-4 standard analog board & & $x$ & & & $x$ & 1 & 0 \\
\hline & $\begin{array}{l}\text { AMS-4 radial entry } \\
\text { sampling head }\end{array}$ & & & & & & & $x$ & & \\
\hline$N / A$ & & LPAS4 & Lamp socket & & $x$ & & & $x$ & 2 & 1 \\
\hline N/A & & LPBU6 & $14 \mathrm{v}$ bulb & & $x$ & & & $x$ & 6 & 2 \\
\hline$N / A$ & & SP28C & Alpha/beta modular detector board & & $x$ & & & $x$ & 1 & 0 \\
\hline \multirow[t]{2}{*}{ N/A } & & SP28D & Gamma modular detector board & & $x$ & & & $x$ & 1 & 0 \\
\hline & $\begin{array}{l}\text { AMS-4 in-line } \\
\text { sampling head }\end{array}$ & & & & & & & & & \\
\hline $\begin{array}{l}\text { FC- } \\
1365 / 6\end{array}$ & & LPAS31 & Lamp socket and lens & & $x$ & & & $x$ & 2 & 1 \\
\hline$N / A$ & & LPBU6 & $14 \mathrm{v}$ bulb & & $x$ & & & $x$ & 6 & 2 \\
\hline N/A & & SP28E & Beta/alpha modular detector board & & $x$ & & & $x$ & 1 & 0 \\
\hline \multirow[t]{3}{*}{ N/A } & & SP28F & Gamma background modular detector board & & $x$ & & & $x$ & 1 & 0 \\
\hline & 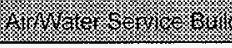 & & & & & & & & 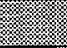 & $(\sqrt[x]{x}$ \\
\hline & & & Spare (onsite) & & & & & & & \\
\hline $\begin{array}{l}\text { WST-LIT- } \\
1306\end{array}$ & $\begin{array}{c}\text { C-106 tank level } \\
\text { indicating transmitter }\end{array}$ & 2655.170 & Enraf 315 ma T slow blow for $110 / 130 \mathrm{VAC}$ & & $x$ & & & $x$ & 12 & 3 \\
\hline N/A & & 2655.173 & Fuse, Enraf 630 ma T slow blow for $220 / 240$ VAC & & $x$ & & & $x$ & 13 & 3 \\
\hline \multirow[t]{2}{*}{ N/A } & & 2655.175 & Fuse, Enraf $1 \mathrm{~A} T$ for $65 \mathrm{VAC}$ & & $x$ & & & $\mathrm{x}$ & 14 & 4 \\
\hline & $\begin{array}{c}\text { Control Panel (s) CP- } \\
01, \mathrm{IE}-1361 / 1362\end{array}$ & & Spare (onsite) & & $x$ & & & & & \\
\hline
\end{tabular}


HNF-2404, Rev. 0

\begin{tabular}{|c|c|c|c|c|c|c|c|c|c|c|}
\hline $\begin{array}{c}\text { Tag } \\
\text { Number }\end{array}$ & System & $\begin{array}{l}\text { Part } \\
\text { Number }\end{array}$ & Part Description & $\begin{array}{l}\text { Critica } \\
\text { Yes }\end{array}$ & $\begin{array}{l}\text { pare } \\
\text { No }\end{array}$ & $\begin{array}{l}\text { Saf } \\
\text { sc }\end{array}$ & ss & GS & $\begin{array}{c}\text { IAR } \\
\text { High }\end{array}$ & $\begin{array}{l}\text { IAR } \\
\text { Low }\end{array}$ \\
\hline$N / A$ & & 312001 & Littlefuse 1A $250 \mathrm{v}$ normal blow & & $x$ & & & $x$ & 4 & 1 \\
\hline N/A & & 313.250 & Littlefuse $1 / 4 \mathrm{~A} 250 \mathrm{v}$ time delay & & $x$ & & & $x$ & 4 & 1 \\
\hline N/A & & 312005 & Littlefuse 5A 250v normal blow & & $x$ & & & $x$ & & \\
\hline N/A & & $800 \mathrm{~T}-\mathrm{N} 169$ & Allen-Bradley $120 \mathrm{v}$ incandescent ANSI 949 & & $x$ & & & $x$ & 4 & 1 \\
\hline N/A & & 6VC52 & Grainger Type T- 1.75 wedge base & & $x$ & & & $x$ & 20 & 5 \\
\hline N/A & & KP12V20 & Square D Class 8501 general-purpose plug-in relay & & $x$ & & & $x$ & 4 & 1 \\
\hline \multirow[t]{3}{*}{ N/A } & & $\mathrm{JCK} 23 \mathrm{~V} 20$ & Square D Class 9050 plug-in variable time delay timer & & $x$ & & & $x$ & 2 & 0 \\
\hline & (6) & & sistis & & & (3) & & $\sqrt{1}$ & & \\
\hline & & & Spare (onsite) & & & & & & & \\
\hline N/A & & N/A & Actuated alumina dessicant & & $x$ & & & $x$ & $25 \mathrm{lb}$ & 0 \\
\hline N/A & & $26-5872$ & Control power fuse (VI-22668, Supp 150) & & $x$ & & & $x$ & 5 & 1 \\
\hline \multirow[t]{3}{*}{$\mathrm{N} / \mathrm{A}$} & & $26-1201$ & $\begin{array}{l}\text { Control air filter } \\
\text { Van Space Air Systems, Inc } \\
2950 \text { Mechanic Street } \\
\text { Lake City PA } \\
\text { (814) } 774-2631\end{array}$ & & $x$ & & & $x$ & 2 & 2 \\
\hline & 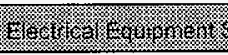 & & & & & 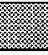 & & & & 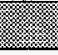 \\
\hline & $\begin{array}{c}\text { Annunciator } 1363 / 4 \\
\text { A\&B }\end{array}$ & & Spare (onsite) & & & & & & & \\
\hline N/A & & $\begin{array}{c}\text { Littlefuse } \\
313.0625 \text { or } \\
\text { Panalarm } \\
110797 \\
\end{array}$ & Time delay fuse $1 / 16 \mathrm{~A} 250 \mathrm{v}$ & & $x$ & & & $x$ & 5 & 2 \\
\hline N/A & & 110738 & Panalarm $1 / 2 A$ 24VDC fuse & & $x$ & & & $x$ & 2 & 0 \\
\hline
\end{tabular}


HNF-2404, Rev. 0

\begin{tabular}{|c|c|c|c|c|c|c|c|c|c|c|}
\hline $\begin{array}{c}\text { Tag } \\
\text { Number }\end{array}$ & System & $\begin{array}{c}\text { Part } \\
\text { Number }\end{array}$ & Part Description & \multicolumn{2}{|c|}{ Critical Spare } & & Safety Class & GS & $\begin{array}{l}\text { IAR } \\
\text { High }\end{array}$ & $\begin{array}{l}\text { IAR } \\
\text { Low }\end{array}$ \\
\hline & 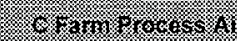 & & & & & & & & & \\
\hline & 4. & & $\sqrt{4.8}$ & & & & & & & \\
\hline & Duct Heater & & Spare (offsite) & & & & & & & \\
\hline & & $\begin{array}{c}161-510046- \\
001\end{array}$ & Chromalox duct heater & & $x$ & & & $x$ & $N / A$ & $\mathrm{~N} / \mathrm{A}$ \\
\hline & $\begin{array}{l}\text { High Efficiency Mist } \\
\text { Eliminator }\end{array}$ & & Spare (onsite) & & & & & & & \\
\hline N/A & & SS-30A05-PM & $\begin{array}{l}\text { CECO filter } \\
\text { CECO Filters, Inc. } \\
\text { (800) 220-8021 }\end{array}$ & & $x$ & & & $x$ & N/A & N/A \\
\hline $\mathrm{N} / \mathrm{A}$ & & S/STL & $\begin{array}{l}1 / 4^{\prime \prime} \text { Mace hollow cone } 90^{\circ} 0.28 \mathrm{gpm} \text { filter spray } \\
\text { nozzles } \\
\text { Beta Fog Nozzle, Inc. }\end{array}$ & & & & & $x$ & N/A & $\mathrm{N} / \mathrm{A}$ \\
\hline $\mathrm{BP} 1361 / 2$ & & & Backflow preventer (see In-Tank Imaging) & & $x$ & & $x$ & & N/A & N/A \\
\hline N/A & & & Spare (offsite) & & & & & & & \\
\hline N/A & & & $\begin{array}{l}\text { Air cooler } \\
\text { KETEMA Heat Transfer Division } \\
2300 \text { West Marshall Drive } \\
\text { Grand Prairie TX } 75051\end{array}$ & & $\mathrm{x}$ & & & $\mathrm{x}$ & N/A & N/A \\
\hline & 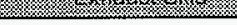 & & & & & & & & & xh \\
\hline & Vacuum Pumps & & Spare (onsite) & & & & & & & \\
\hline & & Gast K-479 & Vacuum pump rebuild kit & & $x$ & & $x$ & & 1 & 0 \\
\hline $\begin{array}{l}296-\mathrm{C}- \\
006\end{array}$ & Isokinetic Air Sampler & & Spare (onsite) & & & & & & & \\
\hline N/A & & BBM 2000 & Neptronic modulating actuator & & $x$ & & & $x$ & 1 & 0 \\
\hline N/A & & $205-430-00$ & IDEC 24VDC $3 \mathrm{~A}$ relay & & $x$ & & & $x$ & 2 & 0 \\
\hline
\end{tabular}




\begin{tabular}{|c|c|c|c|c|c|c|c|c|c|c|}
\hline $\begin{array}{l}\text { Tag } \\
\text { Number }\end{array}$ & System & $\begin{array}{l}\text { Part } \\
\text { Number }\end{array}$ & Part Description & $\begin{array}{r}\text { Critic } \\
\text { Yes }\end{array}$ & $\begin{array}{l}\text { pare } \\
\text { No }\end{array}$ & $\begin{array}{l}\text { Saf } \\
\text { Sc }\end{array}$ & ss & GS & $\begin{array}{l}\text { IAR } \\
\text { High }\end{array}$ & $\begin{array}{l}\text { IAR } \\
\text { Low }\end{array}$ \\
\hline & $\begin{array}{l}\text { Isokinetic Air Sampler } \\
\text { (continued) }\end{array}$ & & & & & & & & & \\
\hline N/A & & 207-504-00 & AMC 120VAC indicating light bulb & & $x$ & & & $\mathrm{x}$ & 3 & 1 \\
\hline N/A & & $207-202-00$ & AMC 24VAC indicating light bulb & & $x$ & & & $x$ & 3 & 1 \\
\hline \multicolumn{11}{|c|}{ entories or ag } \\
\hline & & & $\begin{array}{l}\text { Vendor: } \\
\text { Air Monitor Corp. } \\
\text { 1050 Hopper Avenue } \\
\text { Santa Rosia CA } 95403 \\
\text { (707) 526-9970 }\end{array}$ & & & & & & & \\
\hline & 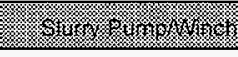 & & (x) & & 8 & & & & & \\
\hline \multirow{9}{*}{$\begin{array}{l}\text { CMC- } \\
0621\end{array}$} & Pump Speed Control & & Spare (vendor agreement) & & $x$ & & & & & \\
\hline & & & Variable speed drive & & $x$ & & & $x$ & N/A & N/A \\
\hline & & & (See AY Farm Variable Speed Drive) & & & & & & & \\
\hline & Winch Control & & Spare (onsite) & & $x$ & & & & & \\
\hline & & & $\begin{array}{l}\text { Winch control panel } \\
\text { construction spare, } 2101 \mathrm{M} / 200 \mathrm{E} \text {, presently in } \\
\text { convenient storage }\end{array}$ & & $x$ & & & $x$ & 1 & 0 \\
\hline & 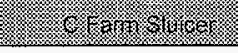 & 8 & $\sqrt{48,8}$ & & & & & & & \\
\hline & Sluicer Assembly & & Spare (onsite) & & & & & & & \\
\hline & & & $\begin{array}{l}\text { Sluicer assembly and control cabinet, } 2101 \mathrm{M} / 200 \mathrm{E} \text {, } \\
\text { presently in convenient storage } \# 43280\end{array}$ & & $x$ & & & $x$ & 1 & 0 \\
\hline & & 313001 & Littlefuse 1A $250 \mathrm{v} 3 \mathrm{AG}$ time delay fuse & & $x$ & & & $\mathrm{x}$ & 5 & 1 \\
\hline
\end{tabular}




\begin{tabular}{|c|c|c|c|c|c|c|c|c|c|c|}
\hline $\begin{array}{l}\text { Tag } \\
\text { Number }\end{array}$ & System & $\begin{array}{l}\text { Part } \\
\text { Number }\end{array}$ & Part Description & \multicolumn{2}{|c|}{$\begin{array}{l}\text { Critical Spare } \\
\text { Yes No }\end{array}$} & \multicolumn{3}{|c|}{ Safety Class } & $\begin{array}{l}\text { IAR } \\
\text { High }\end{array}$ & $\begin{array}{l}\text { IAR } \\
\text { Low }\end{array}$ \\
\hline & & & Spare (offsite) & & & & & & & \\
\hline CCTV-1361 & & RCS-521NBP & Camera & & $x$ & & & $x$ & N/A & N/A \\
\hline CCTV-1361 & & PTE-300S & SST pan and tilt & & $x$ & & & $x$ & N/A & N/A \\
\hline CCTV-1361 & & MN401X & Camera module & & $x$ & & & $x$ & N/A & $\mathrm{N} / \mathrm{A}$ \\
\hline CCTV-1361 & & R12364 & $25^{\prime}$ Mast to local interface unit camera cable & & $x$ & & & $x$ & N/A & N/A \\
\hline $\operatorname{ccTV}-1361$ & & R8504 & $25^{\prime}$ Mast to local interface unit camera cable & & $x$ & & & $x$ & N/A & $N / A$ \\
\hline CCTV-1361 & & 09810 & $25^{\prime}$ Mast to local interface unit cable light & & $x$ & & & $x$ & N/A & $\mathrm{N} / \mathrm{A}$ \\
\hline CCTV-1361 & & RCS-521NBP & Camera O-ring kit & & $x$ & & & $x$ & N/A & $\mathrm{N} / \mathrm{A}$ \\
\hline \multirow[t]{2}{*}{ CCTV-1361 } & & $N / A$ & Lamps, waterproof connectors & & & & & & & \\
\hline & & & Spare (onsite) & & & & & & & \\
\hline \multirow[t]{2}{*}{$\mathrm{BP} 1361 / 2$} & & Series 909 & $\begin{array}{l}\text { Backflow preventer, Series } 909 \text { Repair kit } \\
\text { Watts Regulator Co. } \\
\text { Lawrence MA } 01842\end{array}$ & & $x$ & & & $x$ & 1 & 0 \\
\hline & & & $\begin{array}{l}\text { Vendor: } \\
\text { R. J. Electronics } \\
\text { Salem OR } \\
(503) 362-4733\end{array}$ & & & & & & & \\
\hline \multirow[t]{3}{*}{ NOTE: } & $\begin{array}{l}\text { The majority of } \\
\text { preparations. } \\
\text { identified spare }\end{array}$ & $\begin{array}{l}\text { the In-Tank In } \\
\text { are standard st } \\
\text { weeks. }\end{array}$ & $\begin{array}{l}\text { laging System are dome/pit intrusive and repai } \\
\text { ock items and readily available in a timely man }\end{array}$ & ent can & $\begin{array}{l}\text { be ac } \\
\text { endor }\end{array}$ & $\begin{array}{l}\text { omp } \\
\text { Max }\end{array}$ & $\begin{array}{l}\text { hed } \\
\text { num }\end{array}$ & $\begin{array}{l}\text { ithout } \\
\text { leliver }\end{array}$ & $\begin{array}{l}\text { extens } \\
\text { of all }\end{array}$ & \\
\hline & (2) & & & & & & 3 & 2.8 & & \\
\hline & Chiller Skid & & Spare (offsite) & & & & & & & \\
\hline Chiller & & & Compressor & & $x$ & & & $x$ & & \\
\hline Chiller & & & Motor & & $x$ & & & $x$ & & \\
\hline
\end{tabular}


HNF-2404, Rev. 0

\begin{tabular}{|c|c|c|c|c|c|c|c|c|c|c|}
\hline \multirow[t]{2}{*}{$\begin{array}{l}\text { Tag } \\
\text { Number }\end{array}$} & System & $\begin{array}{c}\text { Part } \\
\text { Number }\end{array}$ & Part Description & \multicolumn{2}{|c|}{$\begin{array}{l}\text { Critical Spare } \\
\text { Yes No }\end{array}$} & \multicolumn{3}{|c|}{ Safety Class } & $\begin{array}{l}\text { IAR } \\
\text { High }\end{array}$ & $\begin{array}{l}\text { IAR } \\
\text { Low }\end{array}$ \\
\hline & $\begin{array}{l}\text { Chiller Skid } \\
\text { (continued) }\end{array}$ & & & & & & & & & \\
\hline Chiller & & & Duplex strainer & & $\mathrm{x}$ & & & $x$ & & \\
\hline Chiller & & & Air separator & & $x$ & & & $x$ & & \\
\hline Chiller & & & Vessel, expansion, make up & & $x$ & & & $x$ & & \\
\hline Chiller & & & $\begin{array}{l}\text { Pump, chilled water } \\
\text { IT Fluid Technology Corp. } \\
\text { (513) } 482-2500\end{array}$ & & $x$ & & & $x$ & & \\
\hline Chiller & & & $\begin{array}{l}\text { Pressure switch/gauge } \\
\text { Dwyer Instruments, Inc } \\
\text { PO Box } 373 \\
\text { Michigan City IN } 46360 \\
\text { (219) } 879-8000\end{array}$ & & $x$ & & & $x$ & & \\
\hline \multirow[t]{2}{*}{ Chiller } & & & $\begin{array}{l}\text { Flowmeter, Wafermag Electromagnetic, 4" } \\
\text { Brooks Instruments } \\
\text { Statesboro, GA }\end{array}$ & & $x$ & & & $x$ & & \\
\hline & & & $\begin{array}{l}\text { Vendor } \\
\text { McGowen Construction Services } \\
\text { Richland WA } 99336\end{array}$ & & & & & & & \\
\hline \multicolumn{11}{|l|}{ NOTE: } \\
\hline \multicolumn{11}{|c|}{ (2) } \\
\hline & (3) & & & & & & & & & \\
\hline & $\begin{array}{l}\text { 702-A Fans, } \mathrm{K} 1-1-1 \\
\text { and } \mathrm{K} 1-1-2\end{array}$ & & & & & & & & & \\
\hline & & & $\begin{array}{l}\text { Motor, } 100 \mathrm{hp} 3600 \mathrm{rpm} 460 \mathrm{v} 60 \mathrm{hz} \text { TEFC, } 405 \text { TS } \\
\text { frame size } \\
\text { (est cost } \$ 5,000 \text { ) }\end{array}$ & & $x$ & & & $x$ & 1 & 0 \\
\hline
\end{tabular}


HNF-2404, Rev. 0

\begin{tabular}{|c|c|c|c|c|c|c|c|c|c|c|}
\hline \multirow[t]{2}{*}{$\begin{array}{c}\text { Tag } \\
\text { Number }\end{array}$} & System & $\begin{array}{c}\text { Part } \\
\text { Number }\end{array}$ & Part Description & \multicolumn{2}{|c|}{ Critical Spare } & \multicolumn{3}{|c|}{ Safety Class } & $\begin{array}{l}\text { IAR } \\
\text { High }\end{array}$ & $\begin{array}{l}\text { IAR } \\
\text { Low }\end{array}$ \\
\hline & $\begin{array}{l}\text { 702-A Fans, K1 } \\
\text { and K1-1-2 } \\
\text { (continued) }\end{array}$ & & & & & & & & & \\
\hline N/A & & SAOL 2 & $\begin{array}{l}\text { Fafnir } 11 / 16^{\prime \prime} \text { bearings } \\
\text { (est cost } \$ 300 \text { ) }\end{array}$ & & $x$ & & & $x$ & 2 & 2 \\
\hline N/A & & & $\begin{array}{l}\text { Kop-Flex size } 21 / 2 \text {, fast full flex } 2 \frac{1}{2} \text { shrouded coupling } \\
\text { (est cost } \$ 400)\end{array}$ & & $x$ & & & $x$ & 1 & 1 \\
\hline N/A & & $\begin{array}{l}\text { O-003-F-03- } \\
\text { O3-NU-13-23- } \\
\text { GGF-U5 or } \\
\text { 0-003-F-00- } \\
\text { NU-13-23- } \\
\text { GGF-U5 }\end{array}$ & Flanders HEPA filters & & $x$ & & & $\mathrm{x}$ & & \\
\hline \multicolumn{11}{|c|}{ 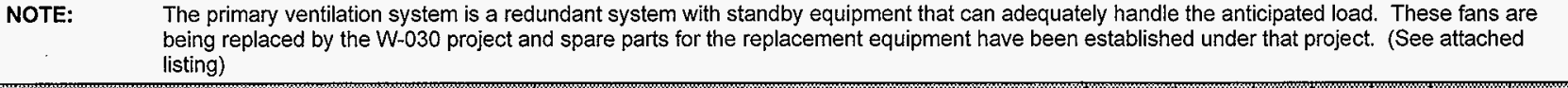 } \\
\hline \multicolumn{11}{|c|}{ (6) } \\
\hline & & & Spare (onsite) & & & & & & & \\
\hline N/A & & 052204 & $\begin{array}{l}\text { Dodge SCM } 111 / 16 \text { " bearings } \\
\text { Exceptions: } \\
\text { Nickel-plated housings, corrosion-resistant fingers, air } \\
\text { handling quality, prelubricated } 100 \% \text { with EP \#2 } \\
\text { grease } \\
\text { Hanford S/N } 6167-0479-6755\end{array}$ & & $x$ & & & $x$ & 2 & 2 \\
\hline$N / A$ & & & $\begin{array}{l}\text { Electric motor, } 15 \mathrm{hp}, 1800 \mathrm{rpm}, 3-\mathrm{phase}, 230 / 460 \mathrm{v} \text {, } \\
60 \mathrm{hz} \\
\text { Hanford S/N } 6117-4055-4400\end{array}$ & & $\mathrm{x}$ & & & $x$ & 1 & 1 \\
\hline N/A & & 560110 & $\begin{array}{l}\text { Browning poly- } V \text { drive belt } \\
\text { stocked by East Area millwrights }\end{array}$ & & $x$ & & & $\mathrm{x}$ & 1 & 1 \\
\hline
\end{tabular}




\begin{tabular}{|c|c|c|c|c|c|c|c|c|c|c|}
\hline $\begin{array}{l}\text { Tag } \\
\text { Number }\end{array}$ & System & $\begin{array}{l}\text { Part } \\
\text { Number }\end{array}$ & Part Description & $\begin{array}{r}\text { Critic } \\
\text { Yes }\end{array}$ & $\begin{array}{l}\text { pare } \\
\text { No }\end{array}$ & Saf & ss & GS & $\begin{array}{l}\text { IAR } \\
\text { High }\end{array}$ & $\begin{array}{l}\text { IAR } \\
\text { Low }\end{array}$ \\
\hline \multicolumn{11}{|c|}{ AY-102 Annulus Exhaust (continued) } \\
\hline N/A & & $\begin{array}{l}\text { T-007-F-03- } \\
05-N U-51-23- \\
\text { GGF-U5 }\end{array}$ & $\begin{array}{l}\text { Flanders liquid seal HEPA element filter } \\
\text { Hanford general stock }\end{array}$ & & $x$ & & & $x$ & 8 & 4 \\
\hline$N / A$ & & & Offsite & & & & & & & \\
\hline N/A & & $332-502-008$ & $\begin{array}{l}\text { American Air Filter inlet prefilters } 24 \text { "x } 24 " \times 4 " 65 \% \\
\text { efficient }\end{array}$ & & $x$ & & & $x$ & & \\
\hline N/A & & $\begin{array}{l}15 Z 20 \mathrm{~J} 1 \mathrm{~T} 12 \mathrm{E} \\
2\end{array}$ & American Air Filter inlet filter $24 " \times 24 " x 4 "$ & & $x$ & & & $x$ & & \\
\hline N/A & & $1 \mathrm{DP} 1=5 / 8$ & $\begin{array}{l}\text { Browning idler assembly bearing belt } \\
\text { Bearings Incorporated } \\
\text { Pasco WA }\end{array}$ & & $x$ & & & $x$ & & \\
\hline
\end{tabular}

In the event of electrical power loss to tank farms, temporary power to operate annulus exhaust systems will be supplied by portable generator(s). These portable generator units are inventoried and maintained as HO-coded equipment and, as such, are maintained by the DynCorp heavy equipment organization. Sufficient spare parts are either maintained in onsite inventories or available through local distributors to ensure equipment availability to support the $\mathrm{C}-106$ sluicing operations. No additional spare parts will be maintained by the project in support of this equipment. In the event of annulus exhaust failure, portable exhausters are available to be used to maintain ventilation. Spare parts for these portable exhausters are listed in Appendix F.

\begin{tabular}{|l|l|l|l|l|l|l|}
\hline &
\end{tabular}

Spares for SHIMS have previously been established within the Hanford Site Inventory System. Spares are inventoried and maintained in the 2101-M warehouse, 200 East Area. Spares are inventoried under stock number(s): 6118-2830-XXXX; 6118-1182-XXXX; 6118-2830-XXX; and 6111-5610-XXXX. Additionally, miscellaneous SHIMS replacement parts are stored in the Hanford Convenient Storage System, 2101-M warehouse, under Author D. D. Tate and Buyer K. S. Hoeft (list attached).

\begin{tabular}{|l|l|l|l|l|l|l|}
\hline & & & \\
\hline
\end{tabular}

Spares for ENRAF have previously been established within the Hanford Site Inventory System. Spares are inventoried and maintained in the $2101-M$ warehouse, 200 East Area. Spares are inventoried under stock number(s): 6118-3448-XXX; 6167-3250-XXXX; 6167-4818-XXXX; 7900-3900-XXXX; 9900-4131-XXXX; and $9900-4150-X X X X$. Spares specific to the $W-320$ project are as follows. Currently, ERAF spares are the responsibility of Mr. John H. Huber, LMHC (list attached). 
HNF-2404, Rev. 0

\begin{tabular}{|c|c|c|c|c|c|c|c|c|c|c|}
\hline \multirow[t]{2}{*}{$\begin{array}{c}\text { Tag } \\
\text { Number }\end{array}$} & System & $\begin{array}{c}\text { Part } \\
\text { Number }\end{array}$ & Part Description & \multicolumn{2}{|c|}{ Critical Spare } & $\begin{array}{l}\text { Saf } \\
\text { sc }\end{array}$ & $\begin{array}{l}\text { Cty } \\
\text { ss }\end{array}$ & $\begin{array}{l}\text { ass } \\
\text { GS }\end{array}$ & $\begin{array}{l}\text { IAR } \\
\text { High }\end{array}$ & $\begin{array}{l}\text { IAR } \\
\text { Low }\end{array}$ \\
\hline & & & $\begin{array}{l}\text { Densitometer } \\
\text { Currently in J. H. Huber's possession, MO- } \\
\text { 028/B108/200W }\end{array}$ & & $x$ & & & $x$ & 1 & \\
\hline & & & Spare(s) (onsite) & & & & & & 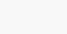 & \\
\hline
\end{tabular}

Currently, TWRS Leak Detector spares have not been established onsite. Replacement parts (see H-2-34965, parts 38 through 43) are onsite and under the custody of R. B. Dunn, 272-AW/200E, 373-4719 (list attached) 


\section{W-320-C-106 WASTE RETRIEVAL PROJECT} SPARE PARTS

Spare parts are categorized by major system, equipment piece, and component.

\begin{tabular}{|c|c|}
\hline SYSTEM & ESTIMATED COST \\
\hline Cathodic Protection & $\$ 90.00$ \\
\hline AY Farm Electrical Distribution & $\$ 11,677.00$ \\
\hline AY Farm Equipment and Instrumentation & $\$ 306.00$ \\
\hline AY Farm Sluicing Pump/Winch & $\$ 12,347.00$ \\
\hline AY Farm 02-E Pit Cooling & $\$ 106.00$ \\
\hline \multicolumn{2}{|l|}{ AY 102 Ventilation } \\
\hline Annulus & $\$ 7,720.00$ \\
\hline Primary & $\$ 4,251.00$ \\
\hline C Farm Electrical Distribution & See AY Farm Electrical Distribution \\
\hline C Farm Equipment and Instrumentation & $\$ 3,402.50$ \\
\hline C Farm Process Air & $\$ 4,061.00$ \\
\hline C Farm Slurry Pump $N$ inch & See AY Farm Sluicing \\
\hline C Farm Sluicer & $\$ 15.00$ \\
\hline C Farm In-Tank Image System & No Charge \\
\hline C Farm Air Inlet Cooling & No Charge \\
\hline Subtotal & $\$ 43,975.50$ \\
\hline Contingency @ 20\% & $\$ 8,795.00$ \\
\hline TOTAL & $\$ 52,770.00$ \\
\hline
\end{tabular}




\section{MEMORANDUM OF UNDERSTANDING \\ W-320 C-106 WASTE RETRIEVABLE PROJECT \\ SPARE PARTS, VARIABLE SPEED DRIVES}

This Memorandum of Understanding (MOU) between Lockheed Martin Hanford Corporation (LMHC), Richland, Washington, and Reliance Electric, Cypress, California, is for the purpose of providing:

1. Spare parts for variable speed drives (Add model numbers and hp datings)

2. Repair technician services at the Hanford Site (Add number of hours required, i.e. $10 \mathrm{Mhs}$, etc.)

3. $24 \mathrm{hr}$. telephone troubleshooting hotline.

These services will be provided for a period of one (1) year, from the date of this agreement, and may be extended for one (1) additional year at the same terms and pricing as the original agreement (Add escalation percentage).

Reliance Electric will ensure that spare parts_(provide a listing) will be maintained at the vendor's facility and will be stored in accordance with ANS! N45.2.2, level "B" storage, for all designated (provide a list) electronic parts and level " $C$ " for all others. LMHC will not be required to purchase a predetermined quantity of spares from this listing. If, at termination of this agreement, $\mathrm{LMHC}$ has not purchased any services or parts from this agreement, then a restocking charge of $\$ .00$, will be assessed. Purchases under this agreement in excess of $\$ .00$ will fulfill the obligations of this agreement and LMHC will not incur any additional charges. Spare parts will be available from Reliance Electric and will be delivered to the Hanford Site within two (2) weeks of such a request.

Technician services will be provided to the site within forty-eight (48) hours of the request. Technicians will provide all tools, instruments, equipment, parts and expertise to adequately troubleshoot and repair normal operational and maintenance failures, having known to exist. Additional technical expertise will be available to the onsite technician via telephone or other electronic means.

A twenty-four (24) hour troubleshooting hotline will be available to LMHC service personnel for assistance in diagnosing onsite problems in a timely manner.

These services will be provided to $\mathrm{LMHC}$ at a price of:

Spare Parts

Technician Services

Troubleshooting Hotline

Subtotal

Additional year Escalation $\$$

Total

\section{$\$$}

$\overline{\$}$ 


\section{MEMORANDUM OF UNDERSTANDING \\ W-320 C-106 WASTE RETRIEVABLE PROJECT \\ SPARE PARTS REQUIREMENTS}

This Memorandum of Understanding between Lockheed Martin Hanford Corporation (LMHC) Richland, Washington, and R. J. Electronics, Salem, Oregon, is for the purpose of ensuring spare parts for the in-tank imaging system provided to the project are available and can be provided to the buyer for the expected life of the project.

The seller, R. J. Electronics, will ensure that spare parts (see Attachment 1) are available to the project for a period of three (3) years from the date of this agreement. The seller will ensure that these spares will be provided, F.O.B. Richland, Washington, on or before eight (8) weeks from receipt of request from the buyer.

Spare parts will be provided as described above and within the terms, conditions and price(s) reached through agreement of the parties at the time of this agreement. 
Selier shall provide to Buyer a list of recommended spare parts considering the expected life of the project. system or equipment to be maintained. The Seller shall propose parts maintained by the Buyer at the Buyer's facility and secondly by Seller at Seller's facility. Seller shall specify whether parts are normal stock items or specific to this request. If normal stock items, seller shall specify their planned duration for maintaining these spares.

Seller shall specify the maximum delivery time of each recommended spare. Seller shall warrant all spare parts to be "As New " throughout the duration of this agreement. Spare parts maintained at Seller's facility will not be the financial responsibility of the buyer until such time as they are required by the buyer. Seller shall propose fee to Buyer for storage and maintenance of such items, if proposed parts are other than normal stock items. Seller shall warrant that spare parts for this item will be available for purchase from the manufacturer for a period of years from initial purchase. 


\section{WARRANTY OF STORED MATERIALS}

Seller warrants that all equipment and materials shall conform with Contract specifications, drawings, and other descriptions and will be of merchantable quality, fit and sufficient for the purposes for which they are intended as evidenced in the Contract. Warranty shall begin upon Buyer's acceptance and extend for a period of one year beyond installation and start-up of equipment/materials. Seller shall provide to Buyer a step-by-step preventive maintenance schedule for Buyer's use during long-term storage of equipment to maintain equipment in warrantable condition. A maintenance schedule shall be contained in a weatherproof package visibly affixed to the equipment and labeled "STORAGE MAINTENANCE SCHEDULE." Buyer's failure to follow maintenance schedule shall cause manufacturer's warranty to be null and void following (Normal Warranty period) the first year of Buyer's initial acceptance of equipment.

If any nonconformity is discovered within the warranty period, Seller shall promptly repair or replace such items. Transportation of replacement items, return of nonconforming items and repeat performance of services shall be at Seller's expense. If repair, replacement or reperformance of services is not timely, Buyer may elect to return the nonconforming items, repair, replace and/or reprocure the item or service at Seller's expense (may be costly or hard to negotiate). This warranty shall restart upon Buyer's acceptance of the repair, replacement or reperformance. 
HNF-2404, Rev. 0

Appendix A

cc:mail Message

L. T. Pedersen to W. H. Hays

$2 / 6 / 98$

\section{Spare Parts W-320 In-tank Imaging System}

The camera vendor has provided a list of recommended spares in his O\&M manual. I believe I sent you a copy of that list last year. Of the items on that list, I believe the most likely to be needed is the replacement lamps. I gather that you have spoken with the vendor and his input is that these lamps (and other parts on his list) could be supplied on an as-needed basis with no extended lead time.

Modifications to the camera system by HiLine Engineering included modifications to the existing :camera cooling gas" flowpath to utilize it for a purge/pressurization source, addition of a pressure switch to the pan-and-tilt housing, addition of 2 relays to the master control unit, and addition of a HiLine Engineering Hazardous Location Power Controller (HLPC) which was modified to mount this item in a NEMA 4X enclosure. Signal from the pressure switch and relays to the HLPC was accomplished by utilization of unused conductors in three of the camera vendors cables. HiLine also provided two cables, one to switch camera system power from the HLPC and one to provide signal path for the pressure switch from the Local Interface unit to the HLPC.

I spoke with Mike Gimera this morning and he indicated that they maintain an on-the-shelf inventory of all HLPC components deemed likely spare part items. These include lamps, fuses, and relays. He also indicated that they could obtain or manufacture any other components used for the $\mathrm{C}-106$ camera modifications in a 1-2 week time frame. I find that satisfactory, and do not believe it necessary to maintain an inventory of spare pasts for the HiLine equipment.

Tom Pedersen 


\author{
Appendix B \\ cc:mail Message \\ Kenneth J. Zubka to William H. Hays \\ January 5, 1998 \\ ENRAF Spares
}

John Huber said you wanted a list of all the ENRAF (level gauge related) material in 200W TWRS (SST) possession. All material located in 2715WA except where noted:

21 ea

1 ea

25 ea**

21 ea

10 ea

12 ea

1 ea

1 ea

1 ea

1 lot

**NOTE:
Level Gauge, ENRAF NONIUS 854 ATG, Model UEAZ854M21F28, with DRUM (located in convenient storage)

Level Gauge, ENRAF NONIUS 854 ATG, Model UEAZ854M21F28, without DRUM (located in convenient storage)

Displacer

Snap

Processing Unit, 4-20MA input, Hart-854 ATG, ENRAF 0854-644 HPU, board w/digital signal based on Hart protocol

Chip, NOVRAM expansion for 854 ATG XPU board, ENRAF 0854-636

MPU Card, ENRAF 0894.648

Circuit board, printed, ENRAF 854.635

Display assembly. ENRAF 854.621

Radar level gauge, ENRAF NONIUS series 872,3 pieces: 1 gauge, 1 stand, 1 controller (located in convenient storage)

Displacers (2 ea) for the W-320 densitometer are on order (3/1/98) and will be inventoried when received. 
Appendix C

$\Omega$ f $H$ HNF-1759, Rev. 1
Spare Parts List

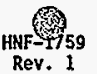

SPARE PARTS FOR WOZO PROJECT

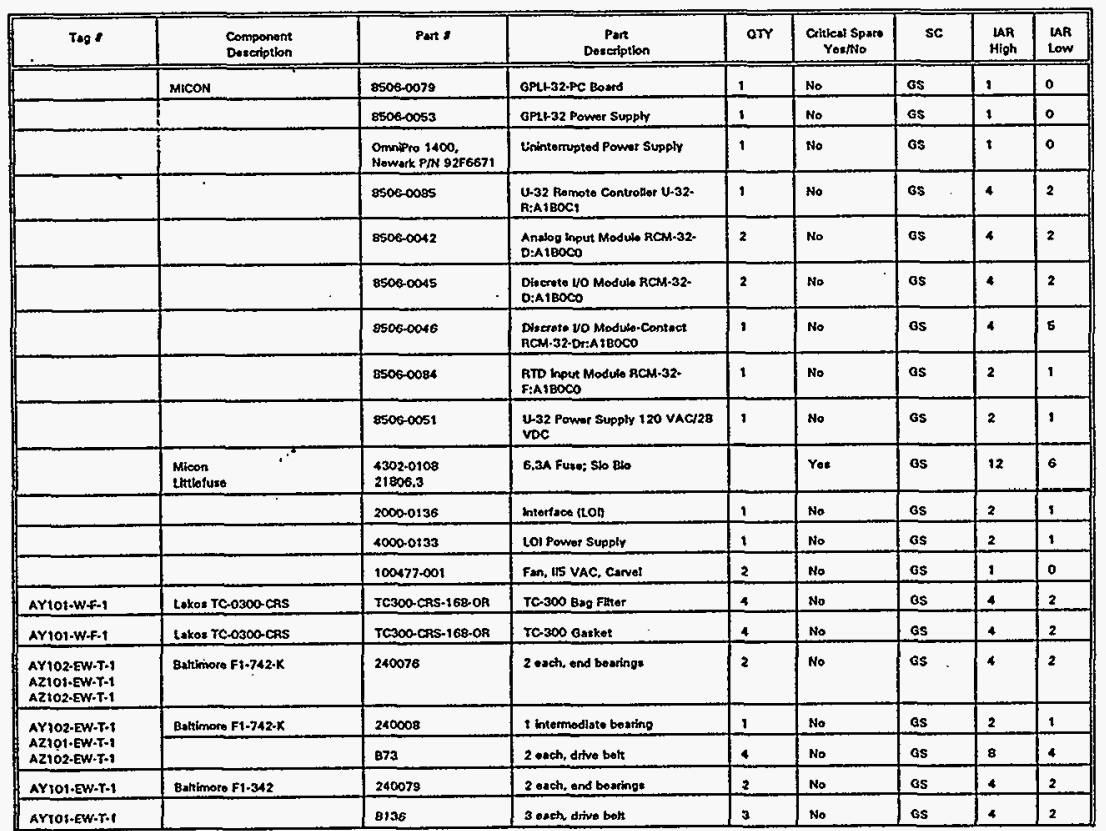




\begin{tabular}{|c|c|c|c|c|c|c|c|c|}
\hline \multicolumn{9}{|c|}{ SPARE PARTS FOR WO3O PROJECT } \\
\hline$T * 0$ & $\begin{array}{l}\text { Component } \\
\text { Dotertption }\end{array}$ & Part : & $\begin{array}{c}\text { Part } \\
\text { Doscription } \\
\end{array}$ & otr & $\begin{array}{c}\text { Critleat Spme } \\
\text { Yos/No }\end{array}$ & sc & $\begin{array}{c}\text { MAR } \\
\text { High }\end{array}$ & $\begin{array}{l}\text { IAR } \\
\text { Low }\end{array}$ \\
\hline \multicolumn{9}{|c|}{ 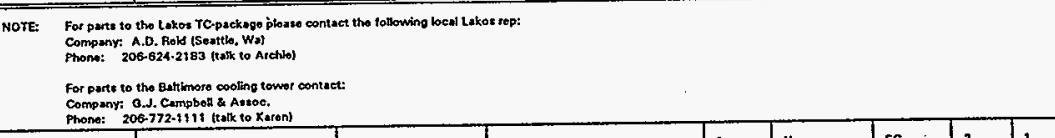 } \\
\hline- & . & & \multirow{9}{*}{ 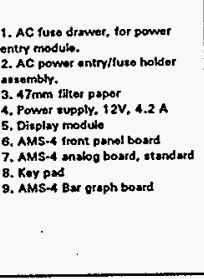 } & 1 & No & sc & 2 & 1 \\
\hline \multirow{8}{*}{ 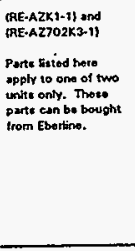 } & \multirow{8}{*}{$\begin{array}{l}\text { Oammin Monitar Sparo Parte } \\
\text { Uitt }\end{array}$} & \multirow{8}{*}{ 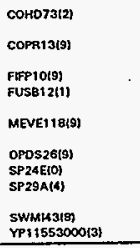 } & & 1 & No & sc & 2 & 1 \\
\hline & & & & 100 & No & sc & 100 & 50 \\
\hline & & & & 1 & No & sc & 2 & 1 \\
\hline & & & & 1 & No & sc & 2 & 1 \\
\hline & & & & 1 & No & sc & 2 & 1 \\
\hline & & & & 1 & No & sc & 2 & 1 \\
\hline & & & & $i$ & No & sc & 2 & 1 \\
\hline & & & & 1 & No & se & 2 & 3 \\
\hline $\begin{array}{l}A z 702 \times 3-11-1 \\
A Z 702 \times 3-11-2\end{array}$ & AMS-4 & $\begin{array}{l}\text { Gaxt 0523-1010. } \\
\text { G5820X } \\
\text { Gott161619 928-517t } \\
\end{array}$ & Vacuoum Pump & tax & No & sc & 1 & 0 \\
\hline $\begin{array}{l}\text { AZK1:-1t:-1 } \\
\text { AZKS:-11:2 } \\
\end{array}$ & AMS-4 & $\begin{array}{l}\text { Oext 1023-101a } \\
\text { Gatt 1616) 926-6171 } \\
\end{array}$ & Vacuonn Pump & tw & No & sc & 1 & 0 \\
\hline \multirow{5}{*}{ 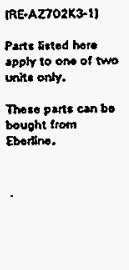 } & \multirow[t]{5}{*}{ 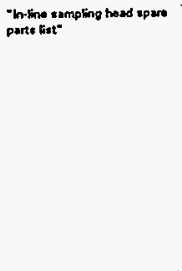 } & SP 28EIG & 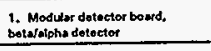 & 1 & so & sc & 2 & 1 \\
\hline & & SP2EF(4) & 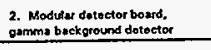 & 1 & No & sc & 2 & 1 \\
\hline & & sWM12213! & 3. Switch (fither door cloxed) & 1 & No & sc & 2 & 1 \\
\hline & & Turazin & $\begin{array}{l}\text { 4. 1- dla coskod gut-proportional } \\
\text { detector flow senror bound }\end{array}$ & 2 & No & sc & 2 & 1 \\
\hline & & $\begin{array}{l}\text { YP1155100017) } \\
\text { SWM122(3) } \\
\text { TUPR217) } \\
\text { Ye11551000177 }\end{array}$ & & $\begin{array}{l}1 \\
1 \\
2 \\
1\end{array}$ & No & se & 2 & 1 \\
\hline
\end{tabular}


HNF-2404, Rev. 0

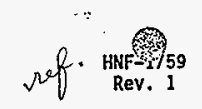

SPARE PARTS FOR WO3O PROJECT

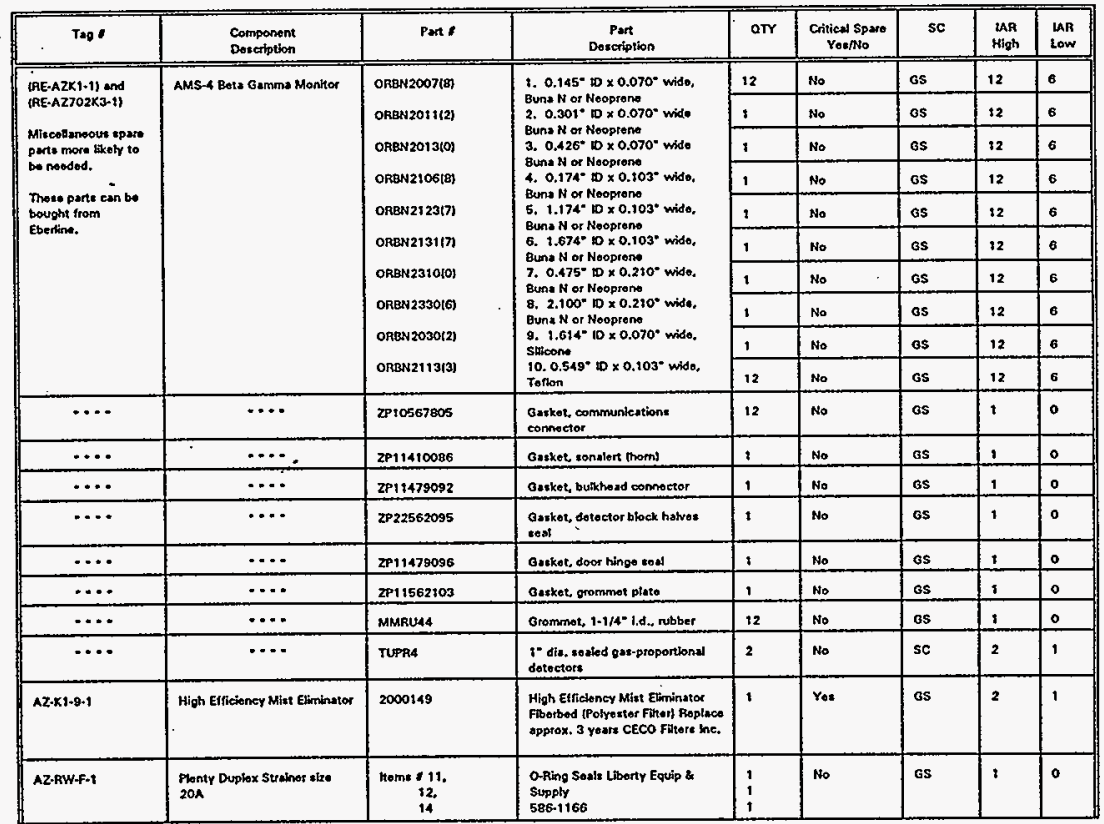


HNF-2404, Rev. 0

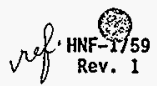

SPARE PARTS FOR YOZO PROJECT

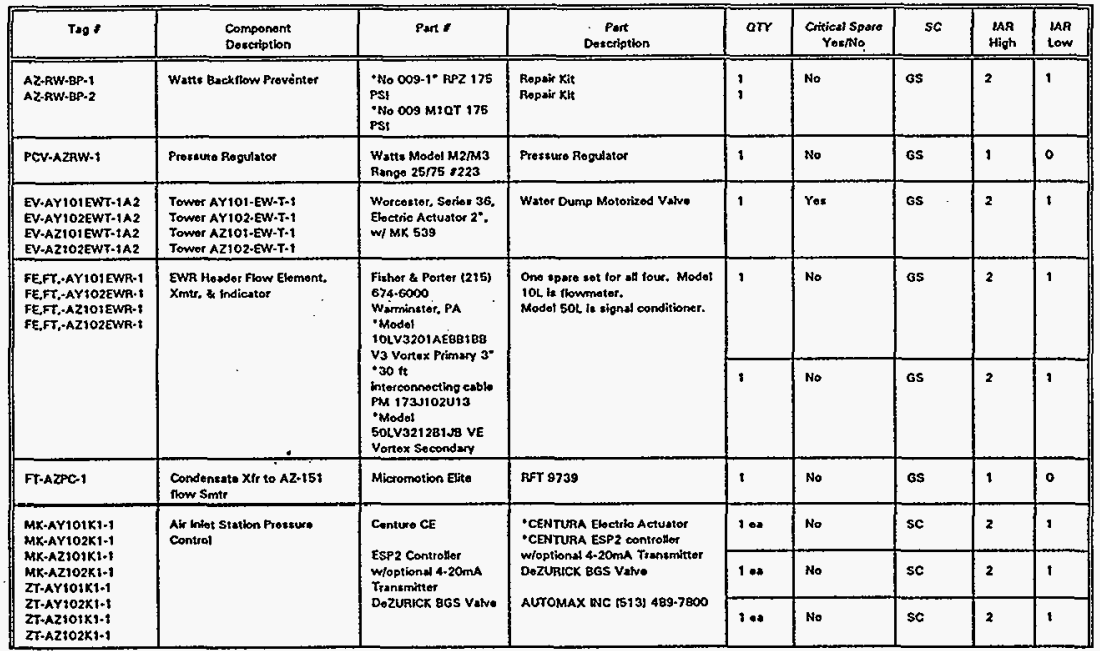




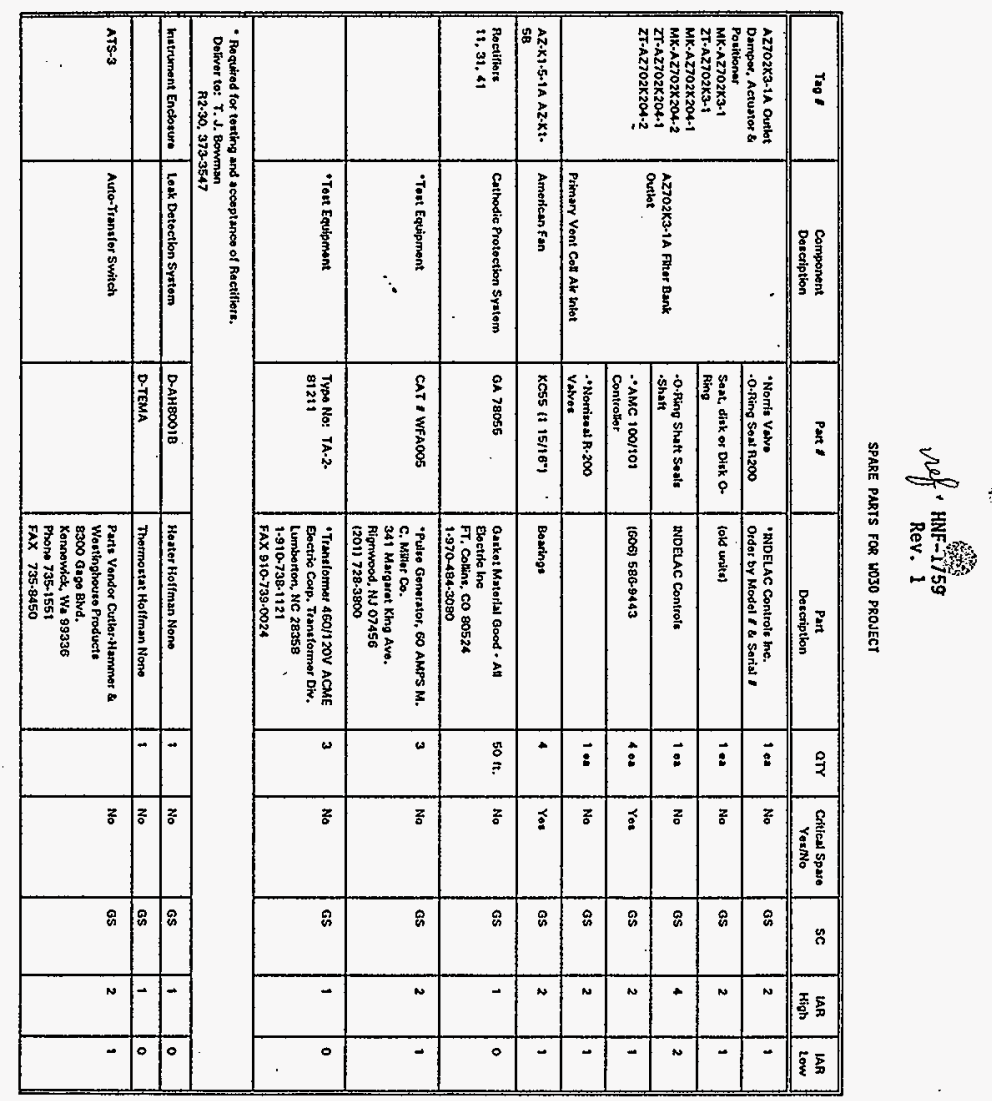

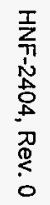


HNF-2404, Rev. 0

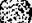

1) HWF- 759

Def. ReV. 1

SPARE PARTS FOR WOZO PROJECI

\begin{tabular}{|c|c|c|c|c|c|c|c|c|}
\hline$T=g$ & $\begin{array}{l}\text { Component } \\
\text { Doscriptlon }\end{array}$ & Pane & $\begin{array}{c}\text { Pant } \\
\text { Doscription }\end{array}$ & ar & $\begin{array}{l}\text { Critical Spers } \\
\text { You/No }\end{array}$ & sc & $\begin{array}{l}\text { IAR } \\
\text { High }\end{array}$ & $\begin{array}{l}\text { IAR } \\
\text { Low }\end{array}$ \\
\hline & , & $\begin{array}{l}\text { CAT No. } \\
\text { ATHSFOA30100XJU }\end{array}$ & $\begin{array}{l}\text { Curtor-Hammor Auto-Matic } \\
\text { Trentlor Switch } \\
\text { Bowror, PA }\end{array}$ & 1 & No & os & 2 & , \\
\hline & & 2820C9B801 & Thre Dolay Cand & 1 & No & Gs & 2 & 3 \\
\hline & & 2820099001 & Volteporfroquoncy Sonsing Card & 2 & no & GS & 2 & 1 \\
\hline & & $1226 \mathrm{c77602}$ & Driver Cosed & 1 & No & Gs & 2 & 1 \\
\hline \multirow[t]{6}{*}{ VFen-st and VFe-i2 } & \multirow{6}{*}{ 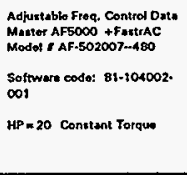 } & \multirow[t]{6}{*}{ AF -502007.480} & Outbut Transistor & , & No & sc & 2 & 1 \\
\hline & & & Bune Driver bosrd & 1 & No & sc & 2 & 1 \\
\hline & & & Pownor Supply Boutd & 1 & No & sc & 2 & 1 \\
\hline & & & Logic Bond & 1 & No & sc & 2 & 1 \\
\hline & & & Mov Aesombly & 1 & No & sc & 2 & 1 \\
\hline & & & Brdop Rectiller Unit & 1 & No & sc & & \\
\hline \multicolumn{9}{|c|}{ 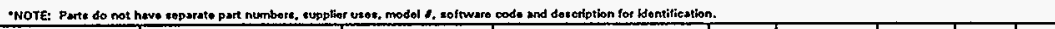 } \\
\hline VSD-1 and VSD-2 & $\begin{array}{l}\text { Varisth Speed Driver } \\
\text { Contronlee }\end{array}$ & $15-00330-0558$ & $\begin{array}{l}\text { Mov Astembly/015-005020- } \\
\text { O10) }\end{array}$ & 1 & No & sc & 1 & 0 \\
\hline & & 15-000575-0149 & $\begin{array}{l}\text { AF5000+ Logic AArsmbly } \\
\text { (AEV.MM/015.5020-0101 }\end{array}$ & 1 & No & sc & 1 & 0 \\
\hline & & $15-000864-0010$ & $\begin{array}{l}\text { Af5000+ bexd intertose/pls- } \\
5020-0101\end{array}$ & 1 & No & sc & , & 0 \\
\hline & & $15-000867-001 t$ & $\begin{array}{l}\text { Ar5000+ 25HP VT Bont } \\
\text { Drivotro15-005020-0101 }\end{array}$ & 1 & No & sc & , & 0 \\
\hline & & $15-000871-0006$ & $\begin{array}{l}\text { AF5000 + 25/504P Powror } \\
\text { Supply/O15-005020.0101 }\end{array}$ & 1 & No & sc & 1 & 0 \\
\hline & & $23-000 t 8 \varepsilon-0242$ & $\begin{array}{l}\text { Reptaced by 9015-299A/O15. } \\
\text { 005020-0101 }\end{array}$ & 2 & No & sc & 1 & 0 \\
\hline & & $53-000501-0001$ & $\begin{array}{l}\text { Contretof, Size }-00^{\circ}, 3 \text { Poto, } \\
\text { 18A/O15-005020-0103 }\end{array}$ & 1 & No & sc & 1 & 0 \\
\hline & & $53-000516-0001$ & $\begin{array}{l}\text { Auxuriay hterlock Contact, } 1 \\
\text { N.0. I N.C.S0:5-005020-0101 }\end{array}$ & $:$ & No & $\mathrm{sc}$ & 1 & 0 \\
\hline & & $53-000449-2102$ & $\begin{array}{l}\text { XFMR DUd POWer DRLNGT. } 1 \mathrm{KV} \\
\text { 50AOO15-005020-0101 }\end{array}$ & 1 & No & sc & 1 & 0 \\
\hline
\end{tabular}


HNF-2404, Rev. 0

$\Omega$. H HF-1759

SPARE PARTS FOR WO30 PROJECT

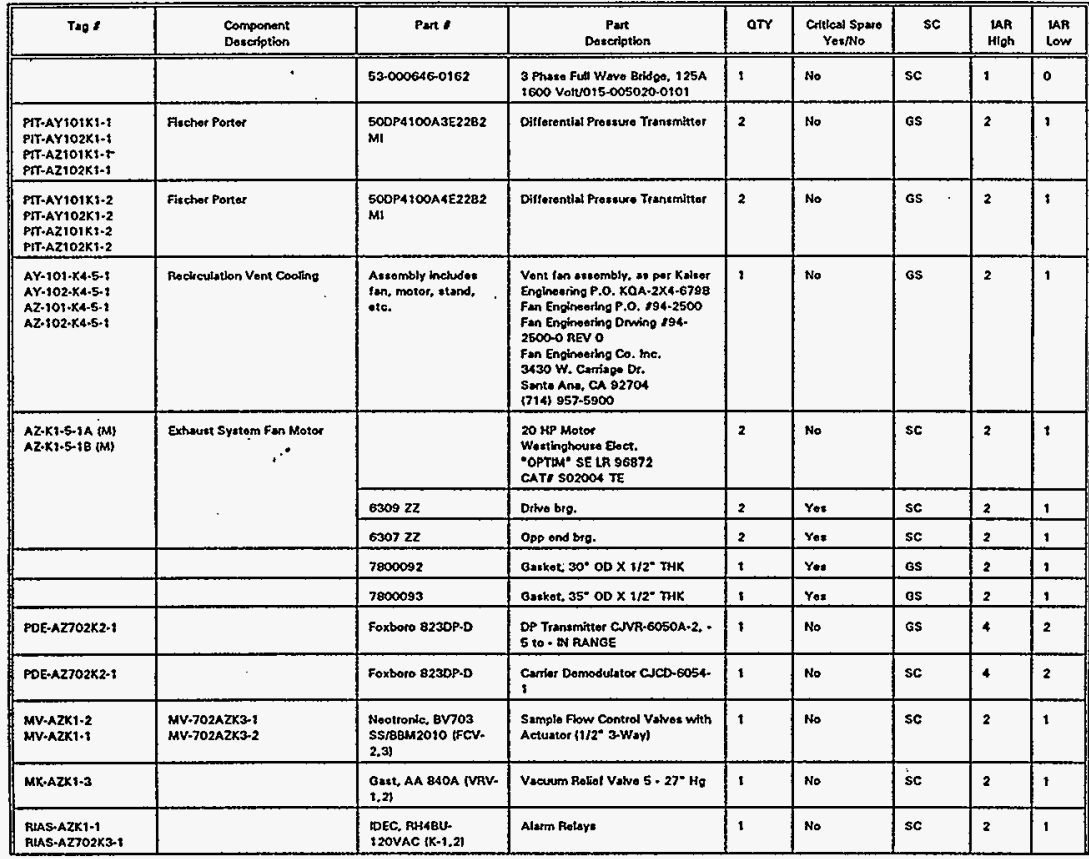


HNF-2404, Rev. 0

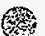

HNF-1759

nef. Rev. 1

SPARE PARTS FOR WO3O PROJECT

\begin{tabular}{|c|c|c|c|c|c|c|c|c|}
\hline Tog * & $\begin{array}{l}\text { Component } \\
\text { Description }\end{array}$ & Part 9 & $\begin{array}{l}\text { Port } \\
\text { Dotcription }\end{array}$ & QTY & $\begin{array}{c}\text { Critleal Spus: } \\
\text { Yos/No }\end{array}$ & sc & $\begin{array}{c}\text { LAR } \\
\text { High }\end{array}$ & $\begin{array}{l}\text { LAR } \\
\text { Low }\end{array}$ \\
\hline & $\dot{-}$ & SP29B(4) & Ebortino AMS-4 andalog board & 20 & Yos & sc & 1 & o \\
\hline & & TUPA4 & $\begin{array}{l}\text { Fbertina AMS-4 Bete Gorrmax } \\
\text { montior }\end{array}$ & 200 & Yes & sc & $:$ & 。 \\
\hline$=$ & & $6 v \times 840$ & Dive bort, Amortean Fan & 400 & Yos: & sc & 4 & 2 \\
\hline & & $x \cos 5$ & $\begin{array}{l}\text { Boading, American Fan, } 1 t \\
\left.15 / 16^{\circ}\right)\end{array}$ & 40 & Yos & sc & 4 & 2 \\
\hline & & FHCO & IIT Earton DP transmittore & 204 & No & ss & 4 & 2 \\
\hline & & 6309.22 & Drvo Eouring & 20 & Yoe & as & 4 & 2 \\
\hline & & 6307.72 & Opostte ond bearing & 20 & You & Gs & 4 & 2 \\
\hline & & 930 VVoscsVAa & 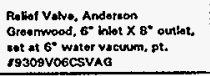 & $1 \ldots$ & Ye: & sc & 2 & 1 \\
\hline & & 29245464 & $\begin{array}{l}\text { 6. Butterfly valve, wafor atylo, } \\
\text { GS Dozurick } 8 B S\end{array}$ & 102 & Yos & sc & I & 0 \\
\hline & $\therefore$ & $\begin{array}{l}0-007-C-03-03-N 12 \\
11-23-0 G-F U 5\end{array}$ & $\begin{array}{l}\text { Fiters, HEPA } 24^{\circ} \times 24^{*} \times 31.5^{\circ} \\
\text { Fundert }\end{array}$ & 4 es & Yes & os & 4 & 2 \\
\hline & & 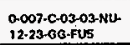 & $\begin{array}{l}\text { Fhere, HEPA } 24^{-} \times 24^{-} \times 11.5^{\circ} \\
\text { Fiandera (Rado vent eyrtem) }\end{array}$ & 2. & Yas & as & 2 & 1 \\
\hline & & $\begin{array}{l}0-007 \cdot \cos -03-\mathrm{Nu} \\
11-23-\mathrm{Co}-\mathrm{Fus}\end{array}$ & $\begin{array}{l}\text { Fitere, HEPA } 12^{-} \times 24^{-} \times 1 t .5^{-} \\
\text {Fiendete (infot ot tulion HEPA' }\end{array}$ & 402 & Yos: & es & 4 & 2 \\
\hline & & $\begin{array}{l}\text { 0-007-C-03-05-NU } \\
\text { 59-23-60-fus }\end{array}$ & $\begin{array}{l}\text { Fitlere, HEPA } 24^{\circ} \times 24^{-} \times 11,5^{-} \\
\text {Findere }(A 2702 \times \times 2 \cdot 4-1,2)\end{array}$ & 204 & Yex & BS & 4 & 2 \\
\hline & & & 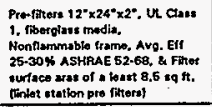 & 400 & Yot & es & 4 & 2 \\
\hline & & & 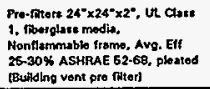 & 204 & Yex & os & 4 & 2 \\
\hline
\end{tabular}


Rev. 1

SPARE PARTS FOR WOSO PROJECT

\begin{tabular}{|c|c|c|c|c|c|c|c|c|}
\hline$r \neq g$ & $\begin{array}{l}\text { Component } \\
\text { Desectiption }\end{array}$ & Part 1 & Patt & arr & $\begin{array}{c}\text { Ceritical Sparo } \\
\text { Yos/No }\end{array}$ & sc & $\begin{array}{l}\text { IAR } \\
\text { High }\end{array}$ & $\begin{array}{l}\text { IAR } \\
\text { LOW }\end{array}$ \\
\hline & 、 & C177ATA & 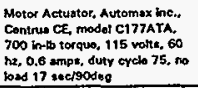 & 100 & No & Gs & 2 & 1 \\
\hline & & $\csc -16-62-N S$ & $\begin{array}{l}\text { Fiter. HEGA, } 24^{\circ} \times 24^{\circ} \times 16^{*} \\
\text { Findindor: }\end{array}$ & 100 & Yet & GS & 2 & : \\
\hline- & & CM1.15955X139 & $\begin{array}{l}\text { Cover seat Linitorque place } r \\
\text { Cose }\end{array}$ & & Yee & sc & 2 & , \\
\hline & & $17300-1600$ & $\begin{array}{l}\text { Mod } 100 \text { actombly. Limlitorats. } \\
\text { pleco no. } 0120\end{array}$ & & Yex & $\mathrm{sc}$ & 8 & 4 \\
\hline & & $17300-1050$ & Oporatho motor, Limitotque & & Yot & sc & 1 & 0 \\
\hline
\end{tabular}


Appendix D

Hanford Spare Parts Catalog

Stock Class/Caption 6111

Sp-oor

HANFORD IHVENTORY PROGRAM

SPARE PARTS CATALOG

IAR NO EOUIPMEHT cOS ENGTHEER BLDG CODE ${ }^{\text {BPF/CVI }} \begin{array}{cc}\text { DATE } \\ \text { PAGE }\end{array}$

STOCK CLASS/CAPTIOH 6111

XCK MUMBER BASIC

PLANT EOUIPMENT DESCRIPTION

INFORMATION ORLY. (GAST P/N 0822-VI03)

$\begin{array}{lc}\text { STOCX MUNBER } & 1 \mathrm{~L} / \mathrm{SC} \\ 6119-5604-3500 & 4 \\ 4\end{array}$

$6111-5610$

$6111-5610$
STOCK NUMBER
6111-5610-5650

STOCK NUMBER

$6111-5610-5655$

${ }_{4}^{I L / S C}$

KIT; SERVICE;

PART DESCRIPTION

THIS KIT IS FOR A GAST VACURM PUMP MOOELS 08Z2-V103, 1022-V103. (GAST P/N X223)

PLAP:

VACUUYY, FOR E/H SAMPLE GALLERY EXHAUST, MFG; GRST, VENDOR; AIR-

PUMP: OIL PRODUCIS, CORP., EP; 202-R.

PUMP, VACUUM, GAST MFS, COMPANY.

E.0. PC. 242-s.
IL/SC PUMP; SAMPLE; PRRT DESCRIPTION
4 GFOR STANDARD HYOROGEN MONITORING EAST \& WEST) MFG: PARKER-RANHIFIN P/N:

$M B-302-X P$

$6119-5612$

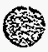

\section{STOCX NUMBER} $6191-5612 \cdot 1700$

$\frac{14 / 5 C}{3}$

PART DESCRIPTION

PUMP; VACUUM; $3 / 4 \mathrm{HP}, 1725 \mathrm{RPM}$

COHTINUOUS DUTY, (GAST MDOEL

1022-V103-G278, TYPICAL S/H 72-411815)

PUMP; VACUUM, OILESS, ROTARY VANE; $3 / 4$

HP; $460 \mathrm{~V}, 3$ PHASE, 10 SCFH; GAST;

1023-9010-6278

DIRECT DRIVE, IHTERNAL FILTER, FOR PUREX

PR STACX MONITORING SYSTEM.

PART DESCRIPTION

FILTER; SUCTION/INTAKE;

FOR GAST VACUSH PUMPA OBO23-VZ AKD

1023-V2 SERIES (LUBRICATED). (GAST P/H

$A B 599)$ IL-39; OA CLAUSES CO2, E14, E22, E34.

$\begin{array}{lc}\text { STOCK NUYBER } & \text { IL/SC } \\ 6111-5612-1705 & 3 \\ & 3\end{array}$

PART DESCRIPTION

FILTER; SUCTJON PORT (INLET);

FOR GAST VACUUN PUMP MOOEL 1023-1010 AND

823.1010. (GAST P/N AK524) IL-30, OA

CLAUSE CO2, E22, E14, E34

STOCK NUMBER $6119 \cdot 5612-5650$

II/SC
3

PART OESCRIPTIOH

PUMP; VACUUM, OILLESS, ROTARY VANE; $3 / 4$

HP

DIRECT DRIVE, INTERHAL FILTER.

Q3, OA CLAUSES CO2, E14, E22, E34

$6111-5615$
PUMP; OILESS VACUUM; $3 / 4 \mathrm{HP}$;

1022-V-103-G272X; (TYPICAL S/N:

72-411815); 115 VAC, 6OHZ, SINGLE PH, TOCFM; GAST:

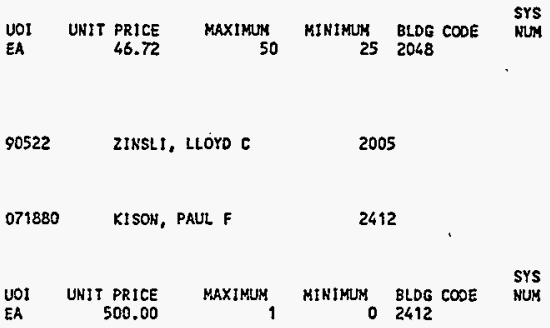

WOI UNIT PRICE MAXINUM MINIMUM BLDG COOE

SYS

EA 602.32 , MAXINUN 02412

ZINSLI, LLOYD C 2005

$\begin{array}{lrrrr}\text { UDI UHIT PRICE } & \text { MAXIMUN } & \text { MINIMUNA } & \text { BLDG COOE } & \text { SYS } \\ \text { EA NUH }\end{array}$

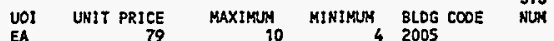

WOA - UNIT PRICE MAXIMUS MINIMUM BLDE CDOE SYS

EA $\because 489.06$ U 02005 MUE NUI

77142 HARLOUIST, ROGER A 2415 
SP-001

STOCK CLASS/CAPTIOH 6117

ICK NUNBER BASIC

STOCK NUNBER

$6197-4010+4405$

$$
{ }_{4}^{1 \mathrm{~L} / \mathrm{SC}}
$$

BOSTOU CEAR $7315 \cdot 50 \cdot R 1$ ASSEHBLY TYPE B POSITION 13, IZOV 1/2 HP BOSTON FRAME J56C PART 8 124514-20 L 1 PHASE TYPE CS 1/2 HP FORM KSD AMP 7.2.3.7.6 VOLT $115 / 230$ CODE 1 RPM 1725 SERIAL F 12 SFEC 53563 (MFG: CENTRUY P/K $8 \cdot 135 \cdot 799 \cdot 20$ )

$6917-4020$

$$
\text { MOTOR; }
$$

16 IMCH VAC EVAP, COOLER, MOTOR, RECIRCULATING PUMP, $L / 3 \mathrm{HP}, 460 \mathrm{~V}$, EP: 234-5, SPF: CVI20619, MFG: CENTURY, S/N: U2, ADD, INFO: MFG. PART NO. 8-135-799-20, FRAME 856J, HERT2 60/5C TIME CONT., RAM 3450/2850, NEMA CODE P

STOCK NUMBER $6117-4020-4611$

$$
\mathrm{IL}_{4} \mathrm{SC}
$$

PART DESCRIPTION

4 MOTOR; RECIRCULATING PUMP:

L/3 HP, 460 V, EP: 234.5 , BPF: CVI20619, KFG: CENTRUY, S/K: UZ, ADO. IHFO: HFG. PART. NO. 8-135-799-20, FRAME 856J, HERT2 60/5C TIME CONT., RAM 3450/2850. NEKA COOE P

6197-4052 MOTOR:

MOTOR; S12E: 1/2 RP; VOLT: 208/230/460; EP: $M-A K U-1, H-A H 7-2$; MFG: CENTURY; TYPE: SC; MDOEL: H275; DWG: H-295511.

$$
\begin{aligned}
& \begin{array}{lcl}
\text { STOCK NUMBER } & \text { IL/SC } & \text { PART DESCRIPTION } \\
6117-4052-4403 & 2 & \text { MOTOR; } \\
\text { MOTOR, 1/2 HP, } 1725 \text { RPM, 208-230/460VAC, }
\end{array} \\
& \text { MOTOR, } 1 / 2 \text { HP, } 1725 \text { RPH, 208-230/460V }
\end{aligned}
$$

$6117-4055$

MOTOR; SC ELECTRIC; $15 \mathrm{HP}$; CENTURY; CATALOE $\mathrm{NO}$. R416

COOE G, $60 \mathrm{HZ}, 3 \mathrm{PH}, 1750 \mathrm{RPH}, 40 / 20 \mathrm{~A}$, 254-T FRAME OPEA DRIP PROOF, 40 DEG C AMB TEMP, 1.15 SERVICE FACTOR, CLASS B INSULATION, NEMA DESIGH B, 230/460V . TYPE SC (CENTURY CATALOG NO. O416)

STOCK NUMBER $6117+4055 \cdot 4400$

\section{IL/SC}

3 FRAME

3 PHASE, $230 / 460$ VAC, $60 \mathrm{kZ}, 1-5 / 8 \mathrm{IH}$.

SHAFT, SERLEO BEARINGS, TEFC CTOTALLY

ENCLOSED FAN COOLED?, WITH OPTIONAL

ASSEMBLY POSITION F-2, U,S. ELECTRICAL

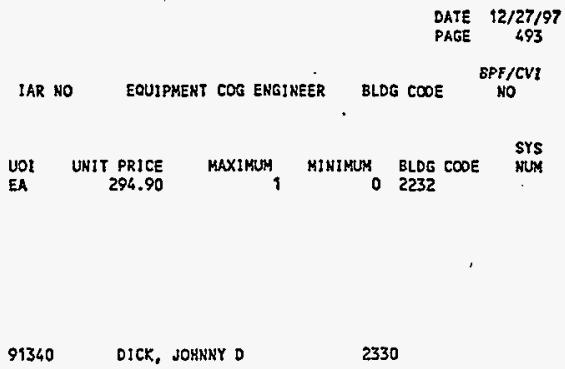


Sp-001
STOCK CLASS/CAPTION 6117

XCK MUNBER BASIC

\begin{tabular}{|c|c|c|}
\hline & & $\begin{array}{l}\text { MOTORS E-407, MOTOR IS EXACT REPLACEMENT } \\
\text { FOR C-105\&106, } 244 C R \text { VAULT } 182,241 A N \\
\text { K2-5-2, } 241 A Y \text { K1-3-2 AND K2-3-2 } \\
\text { EXHAUSIER FAH HOTORS, NO SUBSTITUTE. } \\
\text { SSC/AD: H/A } \\
\text { CLAUSE: } \mathrm{H} / \mathrm{A}\end{array}$ \\
\hline $6917-4056$ & & $\begin{array}{l}\text { MOTOR; EP. NO.: 244-AR; CVI: } 21846 ; \text { HFG: } \\
\text { CENTURY; MODEL: 9-390022-60; ADD } \\
\text { INFO: SPARE PARTS FOR 244-AR VAULT, } \\
\text { PROJECTS B-550, CLOSED LOOP CODLING } \\
\text { SYSTEM, AND B-551, HVAC UPGRADE. }\end{array}$ \\
\hline $\begin{array}{l}\text { STOCK NUNBER } \\
6117-4056-0460\end{array}$ & $\underset{3}{1 L / S C}$ & $\begin{array}{l}\text { PART DESCRIPTIOH } \\
\text { BELT; } \\
\text { BELT, MATCHED SET, P/N A-66-OPIIBELT-VB } \\
\text { S-C PLUS }\end{array}$ \\
\hline $\begin{array}{l}\text { STOCK NUMBER } \\
6117-4056-4415\end{array}$ & $\frac{11 / S C}{4}$ & 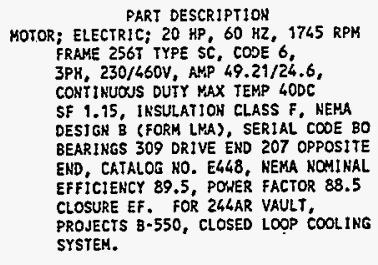 \\
\hline $6117-4058$ & & $\begin{array}{l}\text { MOTOR; } \\
\text { MOTOR, ELECTRIC; MFG: MALLORY SUPPLY CO, } \\
\text { ADD. INFO: FOR EXHAUSTER AT } 241 A H \text { \& } \\
\text { 24IAK. }\end{array}$ \\
\hline $\begin{array}{l}\text { STOCK MUABBER } \\
6197-4058-4408\end{array}$ & $\underset{4}{1 L / S C}$ & $\begin{array}{l}\text { PART DESCRIPTION } \\
\text { MOTOR; ELLCTRIC; } 10 \mathrm{HP}, 1740 \mathrm{RPH} \\
\text { K2-60 FRANE 215T, (230\%460 V, } 3 \text { PHASE } \\
\text { DAYTON MOOEL } 3 \times 341)\end{array}$ \\
\hline $6117-4100$ & & $\begin{array}{l}\text { CONTROLLER; VARIABLE SPEED; NACHINE } \\
\text { DRIVE CO.; } \\
\text { CONTROLLER; VARIABLE SPEED DRIVE; } \\
\text { MACHINE DRIVE CO. }\end{array}$ \\
\hline $\begin{array}{l}\text { STOCK NUNABER } \\
6117-4100-0900\end{array}$ & $\begin{array}{c}\text { IL/SC } \\
2\end{array}$ & $\begin{array}{ll} & \text { PART DESCRIPTIOH } \\
\text { CONTACTOR; } 3 \text { POLE; } \\
\text { CONTACTOR; } 3 \text { POLE; }\end{array}$ \\
\hline $\begin{array}{l}\text { STOCK NUMAER } \\
6117-4100-0901\end{array}$ & $\begin{array}{c}\text { IL/SC } \\
2\end{array}$ & $\begin{array}{l}\text { PART DESCRIPTIOH } \\
\text { INTERLOCK; AUXILIARY; } \\
\text { IUTERLOCK; AUXILIARY; CONTACT; } \\
\text { MACHIHE DRIVE CO MUMBER 53-000516-0001 }\end{array}$ \\
\hline
\end{tabular}

BANFORD INVENTORY PROGRAM SPARE PARTS CATALOO
102702

\begin{tabular}{|c|c|c|c|c|}
\hline \multirow[t]{2}{*}{$\begin{array}{l}\text { UDt } \\
\text { SET }\end{array}$} & $\begin{array}{r}\text { UNIT PRICE } \\
15.00\end{array}$ & MAXIMUM $_{2}$ & ${ }_{2}^{\text {MINIMUM }_{2}}$ & $\begin{array}{l}\text { BLDG COOE } \\
2232\end{array}$ \\
\hline & & & . & \\
\hline $\begin{array}{l}\text { UOI } \\
\text { EA }\end{array}$ & $\begin{array}{r}\text { UNIT PRICE } \\
726.58\end{array}$ & MAXIMUM & MINIMUM $_{0}$ & $\begin{array}{l}\text { BLDG COOE } \\
2232\end{array}$ \\
\hline
\end{tabular}

90194 HICHOLSON, ROSERT S 2047

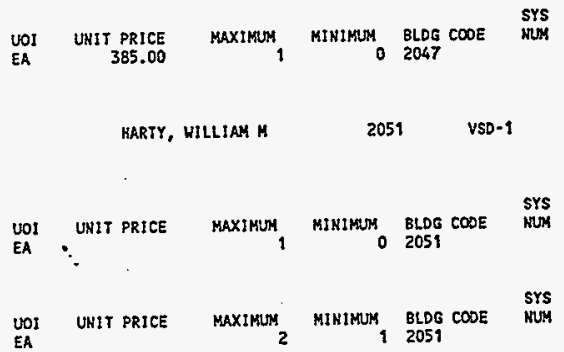


SP-001

STOCK CLASS/CAPTION 6117

JCX NUMBER BASIC

$6117-7820$

STOCK NUMBER $6117 \cdot 7810 \cdot 2505$

$\mathrm{IL} / \mathrm{SC}$
$6197-7800$

MANFORD INYENTORY PROGRAK SPARE PARTS CATALOG

PLANT EQUJPMENT DESCRIPTIOH

CONTROL; TRAHSFORMER; $100 \mathrm{VA}, 60 \mathrm{kZ}, 480$ PRI-VOLTS, 120 SEC, VOLTS; K-2-27968; SQUARE D COMPANY:

CLASS 9070, TYPE E02 (RATIHG: $100 \mathrm{VA}, 60$ HZ, PRI-VOLTS 480, SEC. VOLTS 120; HFt: SQUARE D COKPAIYY (EPK: EF-1-1, EF-1-2; CVI: 20419; DHA: $H-2-27968$ )

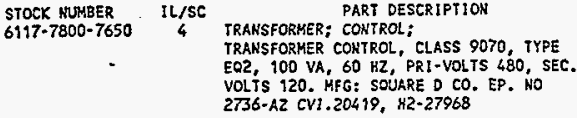

IRANSFORMER, DRY IYPE, POTENTIAL INSIDE, 2400-TO- 120 VOLT, $60 \mathrm{cY}$. COMPENSATED FOR 40 VA, ACCURRCY RATING $150 \mathrm{VA}$, THERMAL RATING 500 VA, USE. 284E MFG-HESTINGHOUSE ELECTRIC CORP.

HOLDER FUSE H C

PART DESCRIPTJOH

HOLDER, FUSE, H/COVER, 2500 VOLT SOLD IN PAIR, 1 EA. NO. 1317268 AND 1 EA. NO. 1317269.

SWITCK: POSITION: $\mathrm{H}-2.98999 ;$ ACCORD; SLI-1

15A SPOT. (ACCORD P/H SL1-9)

SUITCH; POSITIOH; 15 AMP

SPDT. (ACCORD P/N XL11000) CLAUSE CO2, E14, \& E22

$6117-7828$

SHITCH: PONITION; 15A: ACCORD XL13000; H-2-98992; ACCORD; XL13000

OPDT. USED ON FV-EA1-1. (DWE.

H.2-98992, SPEC. NO. B534-CENO6/Y- 106 BPF NO. $22069 / 70$, EPH. FV-EA1+1, 242-A, ACCORD $P / N$ X(13000)

STOCK NUMBER $6117-7828-7300$

IL/SC

SUITCH; ASSEMELY; 15A

USED ON FV-EAT-1. (MOOEL NO. XL13000,

SPEC. NO, B534-CEMOG/Y-106, DWG.

H-2-98992, ACCORD P/N SXLS3) OA

CLAUSES: CO2

SHITCH;

SHITCH, TEMPERATURE; EP: 249.A; MFG: IONEX RESEARCH CORP.; ADD. INFO. 4000 CFM EXHAUSTER, ME-84-267.

\begin{tabular}{|c|c|c|c|}
\hline \multicolumn{4}{|c|}{$\begin{array}{lc}\text { DATE } & 12 / 27 / 97 \\
\text { PAGE } & 529\end{array}$} \\
\hline IAR NO & EOUIPKENT COG ENGIKEER & BLDG CODE & $\begin{array}{c}\text { BPF/CVI } \\
\text { NO }\end{array}$ \\
\hline 37687 & DICK, JOHNNY D & 2338 & 20419 \\
\hline
\end{tabular}

\begin{tabular}{|c|c|c|c|c|}
\hline $\begin{array}{l}\text { vol } \\
\text { EA }\end{array}$ & $\begin{array}{r}\text { UHIT PRICE } \\
25.57\end{array}$ & MAXIRIN $_{2}$ & HIHIMIN & $\begin{array}{l}\text { BLDG COOE } \\
2338\end{array}$ \\
\hline
\end{tabular}

018814

UOI UNIT PRICE MAXIMUK, MINIKUN
PR
10.48

123892 WAKLOUIST, ROGER A $2415 \quad 22069 / 79,78$

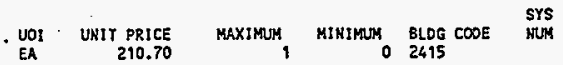
WAHLOUIST, ROGER A $2415 \quad 22069 / 70$

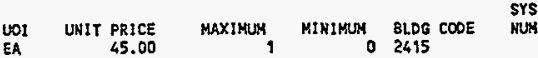

90198 DOOD, RYAH A

2018 


\section{Sp-001 \\ STOCK CLASS/CAPTIOH 6118 \\ " JeK nuMBer basic}

HAKFORD INVENTORY PROGRAM SPARE PARTS CATALOS

PLAHT EOUIPHENT DESCRIPTION CORP. HODEL EVZ-1-\$-0O) OA CLAUSES: $\mathrm{CO} 2$

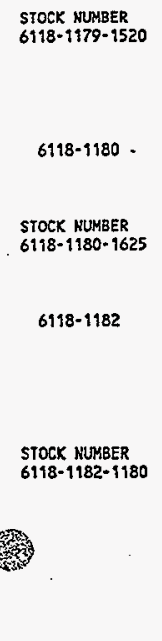

IL/SC

PART DESCRIPIION

ENCOOER; MAGNETO-RESISTIVE;

DYNAPAR CORP. QUBE ROTOPULSER. USED FOR ST-PB2-1. (DWG. H-2-98989, SPEC. NO. B-534/P11, DYWAPAR CORP. MODEL $32-0360-124$ ) OA CLAUSES: COZ

INSTRUMENT PARTS USE E.P. NO. 241-SY B.P.F. 20292, MFR-- AIR MONITOR CORP.

$\pi_{4} \mathrm{TLC}$ PART DESCRIPIIOR FAN-EVALUATOR: DIAMEIER 8 INCHES 280 MIN. CFM, 1400 WAXIMUN CFM, MODEL C. STAINLESS STEEL. (MFE: AIR HONIYOR CORP,'

DETECTOR; DIFFEENIIAL PRESSURE DETECTOR; H-2-83103; AIR MONITOR CORPORATIOH; REFER TO WORK ORDER; MODEL NO. 5000RZ, SERIAL NO. 3636; H-2-83103; SPECI, NO. C-028-C1; 13440 PG 8; DRAUING NO. $\mathrm{H}-2-83103$ REFERS $10 \mathrm{C}-028-\mathrm{ct} \mathrm{Y}-102$

\section{IL/SC PART DESCRIPTIOH
4 \\ STAIHLSTEEL MEMBRAHE;}

HOOEL HO. VELTROH MOOEL 5000 AZ; SPECT. NO. C-028-CI SECTION 13440; RATING: 0.0.35 INCHES WATER GRUGE; 1 PSIG OVERRAHGE S/O: IHSTALLED COMPANENT SH 3636 (H-2-83103) REFER TO WORK ORDER \#16228; EXACT COPY REOUIRED CLAUSES: 924 AD N/A

STOCK NUNBER 6118-1182-1970

$\mathrm{IL} / \mathrm{SC}$
4
4

PART OESCR
FUSE; CIRCUIT BOARD;

RATING: 1.6 AMP; REFER TO WORK ORDER \# 16228 FOR VELTROH MOOEL 5000 AZ D/P CELL TERMINAL BOARD FUSE FI (MFG. NO. AIR MONIIOR CORPORATION P/N 206056) CLAUSES: 924 AD N/A

STOCK NUMBER 6118-1182-1972
$12 / 5 C$

PART DESCRIPTION

FUSE; PICO; DOPED SILICON:

EFER TO WDRK ORDER \# 16228 FOR VELTROH MODEL SODOAZ D/P CELL 15 VDC POHER SUPPLY FUSE F1 ( AIR MONITOR CORPORATION P/N 205843) CLAUSES; 924 (1.0 AMP) AD H/A

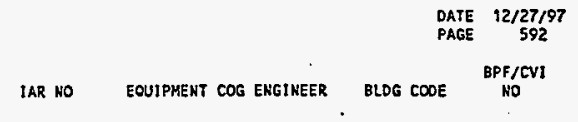
UOI UNIT PRICE MAXIMUN MIMIMUM GLOG COOE SYS EA 750.00 T 2415

77192
SYS $\begin{array}{lrrrr}\text { UOI } & \text { UNIT PRICE } & \text { MAXIMIN } & \text { KINIMUM } & \text { BLDG CODE } \\ \text { EA } & 1505.00 & \text { NIN } & 0 & 2187\end{array}$

OSTERLOR, JAMES D 2216

$\begin{array}{lrrrrr}\text { UOI UNIT PRICE } & \text { MAXIMUMS } & \text { MINIMUM } & \text { BLDG CODE } & \text { SYS } \\ \text { EA } & 1540.00 & & 0 & 2296 & \end{array}$

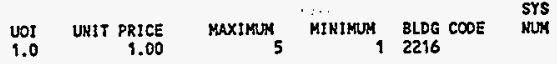

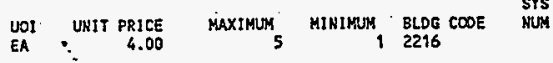




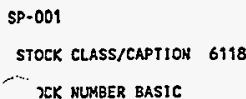

HANFORD IIVENTORY PROGRAY SPARE PARTS CATALOS

PLANT EOUIPHENT DESCRIPTION

$\begin{array}{lc}\text { STOCK NUMBER } & 11 / 5 C \\ 6118-1182-1974 & 4 \\ 4\end{array}$

4 FUSE; PICO. DOPED SIIICON

REFER TO WORK ORDER \#16228 FOR VELTRON MODEL 5000 AZ D/P CELL + I- IS VDC POWER SUPPPLY FUSE F1 (AIR MONITOR CORPORATION P/N 205036) CLAUSES; 924 ( 2.0 AMP) AD N/A

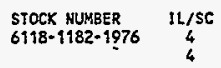
MODEL 500OAZ D/P CC LL + $/-15$ VDC POWER SUPPLY FUSE FZ (AIR MOHITOR CORPOATION; TON CLAUSES: 924 ( $Y / 8$ AMPS AD H/A

STOCK NUMBER 6118-1182-7250 $\frac{\pi}{4} 4 \mathrm{SC}$ SUPPLY; POWER;

PART DESCRIPTION

REFER TO WORK ORDER \# 16228 FOR VELTROH MODEL 5000 AZ ( AIR MONITOR CORPORATIOH: TOM P/M 208217) CLAUSES: 924 AD H/A (115VDC)

$6118-1183$

INSTRUMENT; PARTS; VARIOUS; FOR: STACK AIR MONITOR SYSTEM CMFG: VARIOUS, VENDOR: RIR MONITOR CORPORPORATION)

- - REF, WATER COLUNA: 6418-2331-0912)... - (EPH: 27362B)...

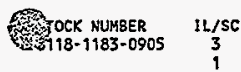

1 CONDITIONER; SIGMRL; I5O0 DUAL OUTPUT, BOTH OUTPUT ARE $4-20$ MILLIAMPS. (MFG: AIR MONITOR CORPORATION P/N 208-012- CHITH 4 MORE DIGITS SIGNIFYING THE S/N)

-- OA ClaUSES: C02, E22 -.

$$
\begin{array}{lcl}
\text { STOCK NUMBER } & \text { IL/SC } & \multicolumn{1}{c}{\text { PART DESCRIPTION }} \\
6118-9183-1590 & 3 & \text { EXIRACTOR; SOUARE ROOT; } \\
& 3 & \text { (MODEL: SERIES 1000, MFG: AIR MONITOR } \\
& \text { CORPORATIOH, VENDOR: SAME, OUTPUT OF } \\
& \text {-4-2V AND INPUT OF 4-20 MA) } \\
& &
\end{array}
$$

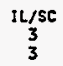

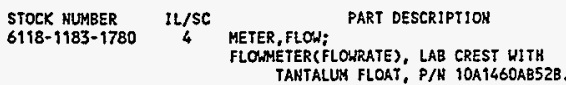

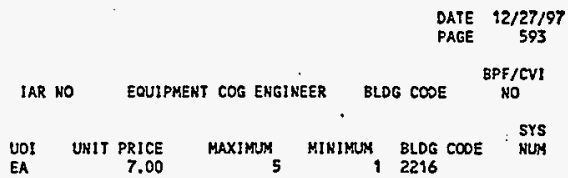




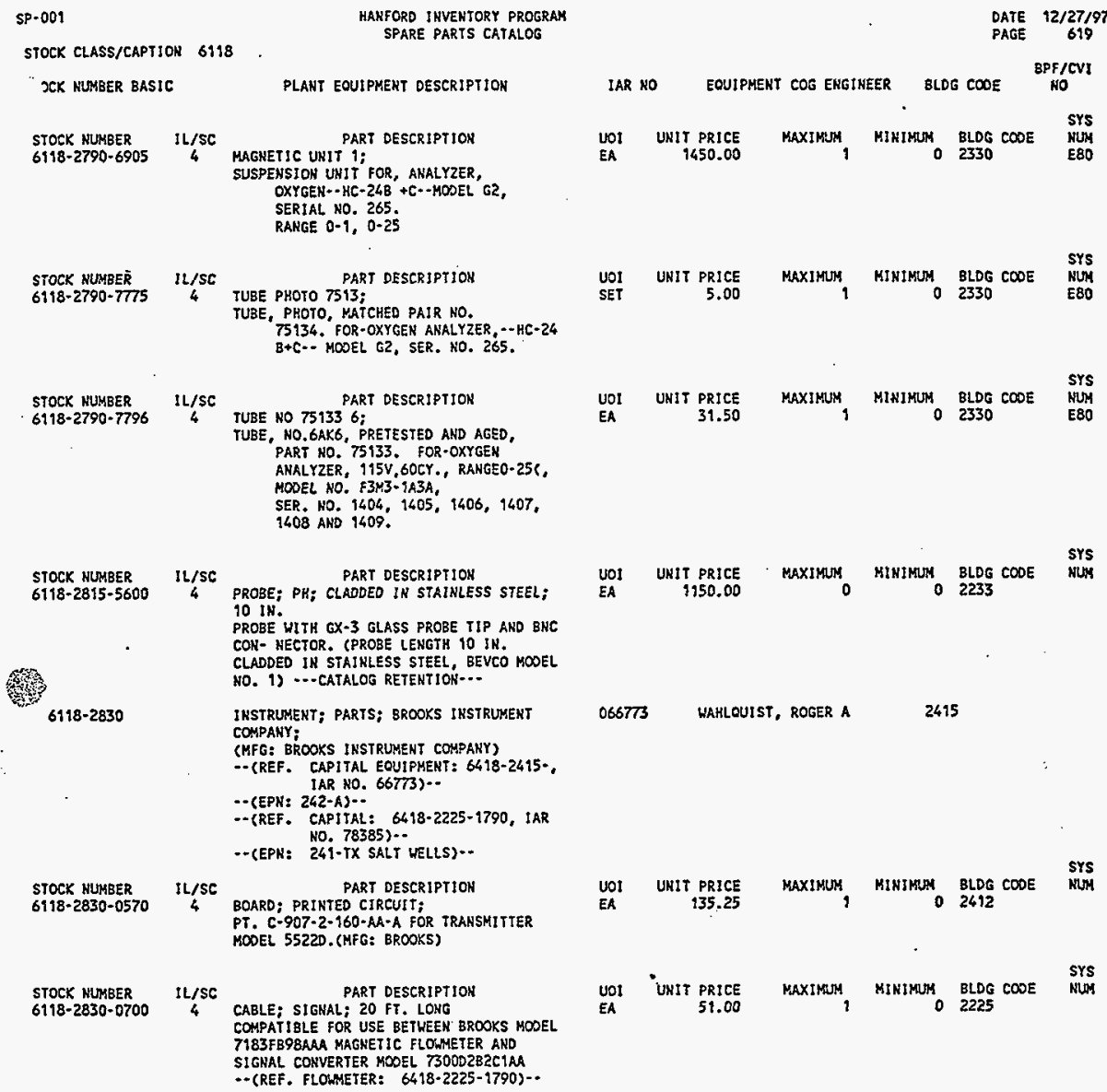


SP-001

STOCX CLASS/CAPTION 6118

CK NUTBEER BASIC

STOCK HUNBER $6118-2830-1790$

IL/SC FLOMETER; AIR;

12 SCFM, MEIER SIZE 8, END

FITTINGS-BRASS. METERIWG

TUBE-BORO-SILICATE GLASS.

O-RINGS-BUKA-K, FLOAT-ALLMINUN.

BROOKS IHSTRUMENT CO. MOOEL 1305.

STOCK RUMBER $6118 \cdot 2830-2970$

IL/SC

INDICATOR; TEMPERATURE;

4 DHG NO: H-2-817853 (FOR EAST \& WEST

STANDARD HYDROGEN MONITCRING) MFG: OYEGA P/K: CNG11IA

STOCK NUMBER $6118-2830-4420$

IL/SC
4

PART DESCRIPTION

MONITOR; HYDROGEN:

4 DUG NO: H-2-817853 (FOR EAST \& WEST TANK FARMS STANDARD HYDROGEN MONITORING) HFG: NEUPORT ELECTRONICS P/R:

INFU-0-0-1-0-DC:

STOCX MUMBER 6118-2830-5580

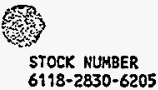

$11 / 56$
4
4

PART DESCRIPIION
SUPPLY; PONER:

(HFG: BROOKS; P/H: S-6412-022-AAR;

VENDOR: BROOKS INSTRUMENT DIVISION)

RATING: STANDARD 42V) (FOR: MOOEL 5522D

TRANSMITTER, S/N 721137217+ SALT WELL

PUAPING) GLAUSE: N/A IL 4

STOCK NUMBER
6118-2830-620

$11 / \mathrm{SC}$

METER; 6.65E PART DESCRIPTION

O-120 SCFH AIR AT S.T.P.

SIZE 6-65E, FISCHER-PORTER HOOEL 1OA3135-N, CAT. NO. A313510, EQ.USE $271 \cdot 8$.

STOCK HUMBER $6118-2830-6210$

$11 / \mathrm{SC}$

ROTONETER;

PART DESCRIPYION

(INDICATIHG, EP-225-B. BROOKS INSTRUMENT

CO. HOOEL 1305 WITH INTEGRAL NEEDLE

VALVE, 1.0 TO 10 (FH) IL 4

STOCK MUMBER
$6118-2830-7700$

$I_{4}^{I L / S C}$

PART DESCRIPTIOH

TUBE; TRU-TAPER; $R-B H-75-1$

FOR BROOKS SHO-RATE

RATEHETER, AIR I2 SCFM, METER SIZE

8. METERIMG TUBE BOROSCILICATE

GLASS, O RINGS, BUNA-H FLOAT,

ALUMI HUM. BROOKS TYPE 1305

TYPICAL SER. HO. 6307-5221616.

$6118-2850$

INSTRUMENT PARTS
DATE $12 / 27 / 97$

PAGE 621

IAR NO EOUIPMENT COS EMGINEER BLDG COOE $\begin{gathered}\mathrm{BPF} / \mathrm{CV} \text { NO } \\ \text { Ho }\end{gathered}$

$$
\begin{aligned}
& \text { UOI UNIT PRICE MXIMUNS MINIMUN BLDG COSE SYS }
\end{aligned}
$$

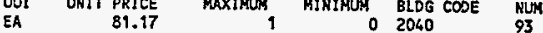

$\begin{array}{lrrrrr}\text { UOI UNIT PRICE } & \text { MAXIMUM } & \text { MINIMLN } & \text { ELDG CODE } & \text { SYS } \\ \text { EA } & 292.00 & 1 & 0 & 2412 & \end{array}$

UOI UNIT PRICE

MAXIMUN MINIHUM BLDG COOE

SYS

EA 755.00 MAXIMIN, MINIHUR 1 BLDG COOE NUN

$\begin{array}{lrrrr}\text { UOI UNIT PRICE } & \text { MAXINUY, MINIMUM } & \text { BLDG COOE } & \text { SYS } \\ \text { EA } & 275.50 & & \end{array}$

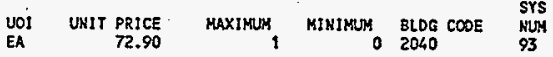

EA ONIT PRICE HAXIMUN, MIMIMUN

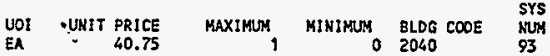




$$
\text { sp-0oi }
$$

STOCK CLASS/CAPTION 6118

CK nUABER basIC

$6118-3448$

STOCK MUMBER
6118-3648-0456-
STOCK NUNBER
6118-3448-1180
STOCK NUMBER
6118-3448-1270
STOCK NUNABER
$6118-3448-1590$

STOCK NUNBER 6118-3448-2070

STOCK NUWBER $6118-3448-2230$

$6118-3450$
HANFORO INVENTORY PROGRAM SPARE PARTS CATALOG

PLANT EOUIPMENT DESCRIPTION

GAUGE; LEVEL DETECTOR; H-2-817634; ENRAF INCORPORATED;

SERIES 854 ATO LEVEL DETECTOR) (MFG: ENRAF INCORPORATED) (CVI: 39560001 004; DNG: H-2-817634)

$$
\begin{gathered}
\text { IL.SC PART DESCRIPTION } \\
3 \text { MEARING; DRUN; } \\
\text { MFG: ENRAF NONIUS P/N: } 0854.953 \\
\text { CLAUSES: C02, E14, E22 }
\end{gathered}
$$

$$
\begin{array}{cl}
\text { IL/SC } & \text { PART DESCRIPTIOH } \\
3 & \begin{array}{l}
\text { DISPLACER; } \\
\text { MFG: ENRAF NONIUS P/N: }
\end{array} \\
\text { CLAUSES: CO2, E14, E22 }
\end{array}
$$

$$
\begin{array}{cl}
\text { IL/SC PART DESCRIPTION } \\
3 \text { DRUM; } \\
\text { CFOR: ENRAF EOUIPMENT, (PLATINUM-20\% } \\
\text { IR1DIUM]). MFG: ENRAF HONIUS P/N: } \\
\text { 9954.962 CLAUSES: CO2, E14, E22 }
\end{array}
$$

$$
\begin{aligned}
& \text { IL/SC PART DESCRIPTIOH } \\
& 3 \text { EYELET; WIRE MEASURING; } \\
& \text { MFG: ENRAF MONIUS P/N: 0105.347 } \\
& \text { CLAUSES: CO2, E14, E22 }
\end{aligned}
$$
IL/SE PART OESCRIPTION GASKET; CIRCULAR; FIBRE; FOR A 4" FIG. 215-CS

(FOR A FIG. 215-CS SIGHT FLON INDICATOR) (MFG: ERHST GAUGE COMPAN; P/N 0105.347) CLAUSE: CO3 CLAUSE: 917 / 5 YEARS

\begin{tabular}{|c|c|c|c|}
\hline \multirow[b]{2}{*}{ IAR NO } & \multirow[b]{2}{*}{ EOUIPHENT COS ENGINEER } & $\begin{array}{l}\text { DATE } \\
\text { PAGE }\end{array}$ & $\begin{array}{cc}12 / 27 / 97 \\
\text { SE } & 655\end{array}$ \\
\hline & & BLOG COOE & $\begin{array}{c}\text { BPF/CVI } \\
\text { HO }\end{array}$ \\
\hline & HUBER, JOHK H & 2420 & 31560 \\
\hline
\end{tabular}
SHELF LIFE
IL/SC PART DESCRIPTIOH
GAUGE; LEVEL DETECTOR;
3 SERIES 854 ATG, WITH DISPLACER P/K O815.900. MFE: ENRAF; MOOEL: UEAN854M21F28/LC.2-U5 (OHG: H-2-817634) CLAUSES: C02, E14, E22 $A D: Q$ PART OESCRIPIIOH
GLASS; TEMPERED; FOR $4 *$ FIG. 215-CS
SFOR 4 4 215-CS SIGHT FLOH INDICATORS
MFG: ERHST GAUGE CO CLAUSE: CO3 LEVEL: CONTROL;

INSTRLNEHT PARTS, MFG. LEEOS AND NORTHRUP. LIDUID LEVEL INDICATING INST. EP 234-52. 261K. VACUUM SYSTEM CVI 20612.

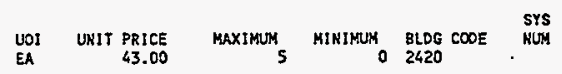

$\begin{array}{lrrrrr}\text { UOI UNIT PRICE } & \text { MAXIMUM } & \text { MINIMUM } & \text { BLDG COOE } & \text { SYS } \\ \text { ER NUNH } & 389.00 & 5 & 0 & 2420 & \end{array}$

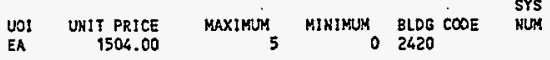

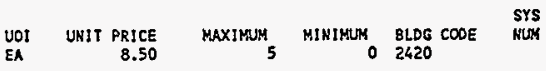

UOI UNIT PRICE MAXIMUN MINIHUM BLDG COOE NYS

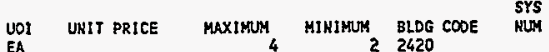

$\begin{array}{lrrrrr}\text { VOI } & \text { UNIT PRICE } & \text { MAXIMUS } & \text { MINIMUM } & \text { BLDG CODE } \\ \text { EA } & \because & 68.40 & 10 & 0 & 2420\end{array}$

87324 THOHAS, RJCHARD J 2330 
SP-001

STOCK CLASS/CAPTION 6167

ICK NUMBER BASIC

$6167+3250$

\begin{abstract}
STOCK NUMBER
\end{abstract} 6167-3250-0450

$I_{3}^{I L / S C}$

EAN; CENTRIFUGAL; ALADDIN; 241AY-K1-3-2, $249 A Y-K 2 \cdot 3 \cdot 2$

EXHAUSTER K9-3-2 AND K2-3-2 FOR 101 AND

102 AY ANRULUS EXHAUSTER FANS, 241-AY

FARH - TANK FARHS EAST. P.O. NO.

JAJ-D-T7742 ITEK 2. CALADDIN P/A

$241 A Y-K 1-3-2,249 A Y-K 2-3-2)$

MAFORD INVENTORY PROGRAM

SPARE PARTS CATALOS

FAN; EXHAUSTER:

FAN, EXHAUSIER, $3 / 4 \mathrm{HP}, 1140 \mathrm{RPM}$.

USE EP $234-5 \quad 10430-23$, BPF 4365. ALLADDIN HERTING CORPORATION TYPE BB, \$I2E $131 / 2$, SINGLE INLET SINGLE WIOTH, CLOCKHISE ROTATION, ARRANGEMENT NO. 2, CLASS 1, REF DWG 485-AC-1. SERIAL 4365. (EVI: 1387)

STOCK RUMBER $6167-3300-0535$

$$
11 / \mathrm{sC}
$$

PART DESCRIPIION

BELTS, SET OF 2

BELT, 50.300 tN. OC, 48.000 IN. IC, $.500 \mathrm{TH}, .344 \mathrm{~T}$, FACTORY MATCKED SETS OF 2 BELTS. IDBI GROJP 71487.

$6167+3305$

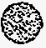

FAN; CENTRIFUGAL EXHAUST; FAR

ENGIHEER IHG;

(MFG: FAH ENGIMEERING) (SERIAL EF\%, EF2 AND EF3)

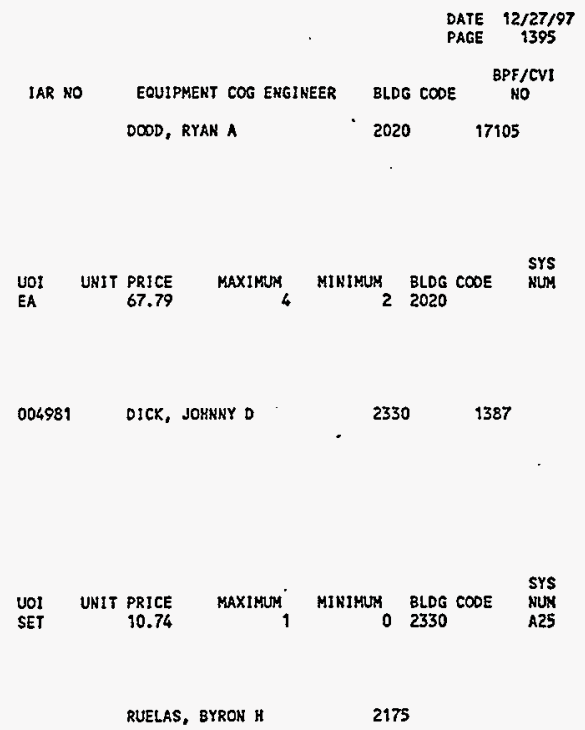

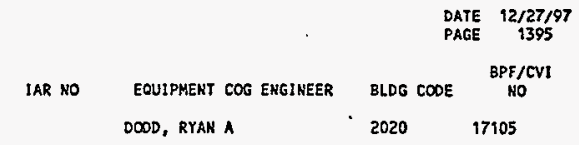
UOI UNIT PRICE MAXIMUA MININUM BLDG COOE \$YS $\begin{array}{llrr}\text { EA } & 67.79 & 4 & 2020\end{array}$

004981 DICK, JOKNKY D $2330 \quad 1387$

STOCK NUMBER $6167-3305-0451$

PART DESCRIPYIOH

BEARING; PILLOW BLOCK ASSEMBLY; 3 15/16

IN. SHRFT DIAMETER

COMPLETE ASSEMBLY COHSISIING OF HOUSIKG, SPHERICAL ROLLER BEARING, TAPERLOCK ADAPTOR, RING SERLS AND STABILIZING RING. (SKF MODEL SAF 22522(A) OR EQUAL, VENDOR: BEARINGS, INCORPORATED) - - (THIS UNIT IS USED AS IHE OUTBORRD OR FIXED BEARING FOR 222-S PRIMARY EXHAUST FAHS.) - -

STOCK NUMBER $6167+3305-0452$

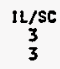

PART DESCRIPTION
BEARING; INSERT; 3 7/16"

SKF EOUAL IS FSAF.

22520 IHIS IS A COMPLETE UNIT.CTO BE USED ON THE ELECTRIC EXHAUST FRNS AT 222-\$3 CLAUSE 924,1130 
sp.001

STOCK CLASS/CAPTION 6167

CK MUMBER BASIC

STOCK NLMBER 6167-4813-0415

IL/SC
3

BAG; MEPA FILTER CHANGE OUT; PVC; $60 C X$ 54

FLANDERS P/N PVC-Y-T5P- 8.

TO FIT HOUSIHG NUMBER HP G-1 IR-CC-D (304)F.

SSC/AD: $3 / 0$

CLAUSE: 834

STOCK HUNBER $6167-4813-1725$

$11 / 56$

PART DESCRIPTION

FILTER; NUCLEAR GRADE REPA;
HAMFORD INVEKTORY PROGRAM SPARE PARTS CATALOG

PLANT EQUIPMENT DESCRIPTIOY

PART DESCRIPIION

FIRE-, MOISTURE-, AND CHEMICAL-RESISTART GFMCR), PER KS-V-P-4042 AMENDMENT 1. NOMIHAL AIRFLOU RATING: 125 CFM MAXIMUM, RESISTANCE AT THE MOYIKAL AIRFLOH RATIMG: AT 1.3 IN. WG.

FLANDER MODEL / $P / H$ :

$0-007-D-03-05-1 U-51-23-C C D-U 5$

$0=$ FRAME HARDWARE: N/A

007 = FILTER MEDIUM: $99.97 \%$ W/R GLASS STANDARO PRODUCT

$D=$ PACK STYLE: $4 \mathrm{IN}$. PUREFORM ELENENT

OS = FRAME CONSTRUCTION MATERIAL TYPE: 14-GAUGE TYPE 304 SS

$05=$ FRAME STYLE (FLANGES): $3 / 4^{\prime \prime}$ DEEP CHANHEL (OR GRODVE) EILLEO HITH SEALANT

NU = NUCLEAR GRADE FILTERS: F,R. URETHANE

51 = FILTER/MOUNTING FRAME: BLUE-GEL FILTER/MOUNTJNG FRAME GASKET LOCATION- UPSTREAM

23 = FACEGUARD SPECIFICATION: SS $(4 X$ 4 MESH) 304/304L SS WIRE CLOTH FACEGUARD LOCATION: UPSTREAM AHD DOUNSTREAM

CCD $=$ FILTER CODE SIZE: $12 \times 12 \times 57 / 8$ INCHES

US $=U L$ IESTED WITH 586 LABELS

- FILTERS SHALL BE IN ACCORDANCE MITH SPECIFICATIOH KS-V-P-4042 AMENDMENT 1.

- TO BE TESTED AT WHC HEPA FILTER TEST

FACILITY.

- CON-SITE REFEREMCE - KPS-159-H)

CLAUSES: CO2, E01,. E02, E16, E17 AD: Q

$6967-4814$
HOUSING COMMERCIAL FILTERS

BSSB10-3/4SD; 316 S5; 10 IN;

8SSB10-3/4SD; H-2-29661, H-2-29662;

COMMERCIAL FILTERS; BSSB $10-3 / 4$ SD

MANUFACTURED $8 Y$ COYMERCIAL FILTERS FOR

10 IH CARTRIDGE FILTER. (TO BE USED IN

PRF $(236-Z)$ CHEM PREP ON TANKS A101,

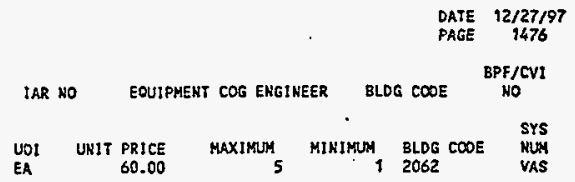


SP+001

STOCK CLASS/CAPTION 6167

ICK NUMBER BASIC

PLAKT EOUIPMENT DESCRIPTION

A102,A103, A104, A105, A108, A109, A112, A113, A114, A115, AND A116;

STOCK MLMEER
$6167-4814-9500$ $1 \mathrm{~L} / \mathrm{SC}$

ELEMENT;

PART DESCRIPTION

ELEMENT, FILTER, HONEYCOMB, FUL FLO, STOCK NO. 17R10.SV, FOR ABOVE FILTER, hIGH USAGE.

STOCK NUHBER $6167-4814-1720$

IL/SC
3
3

PART DESCRIPTION

HOUSING; FILTER; 316 SS;

10 IN CARTRIDGE FILTER. (COMMERCIAL

FILTER P/K BSSB:0-3/4SD) 1130

STOCK NUMSER 6167-4814-2000 $11 / 3 C$

GASKET; O-RING; VITOH;

LMFG: COAMERCIAL FILTERS: $P / N$ :

4150-5179; VENDOR: MONTGONERY BROTHERS

COAPANY) (FOR: COWMERCIAL FILTER HOUSING BSSB10-3/4SD AND BSS $10-3 / 4$ SD 3 SHELF LIFE CLAUSE: $917 / 20$ YEARS

SHELF LIFE CLAUSE 917

$6167-4815$

FILTER, ROLL PAK

AMERICAN AIR FILTER

STOCK NUMBER

$6167-4815-4300$

$11 / \mathrm{SC}$

FILTER MEDIA;

FILTER, FIBER GLASS MEDIA, ROLL TYPE

33 INCH WIDE $X$ 65 FEET LONG. AMERICAN AIR FILTER CATALOG NO. 811 - $935-002$.

5. STOCK MUMBER $6167-4815-4350$

IL/SC
4
3

PART DESCRIPTION

FILTER; ROLL TYPE; FIBER GLASS MEDIA; 46

IH. HIDE X 65 FT. LONG

(HFG: AMERICAN AIR FILTER; NO:

$800-947-2)$ CLAUSE: N/A

IL. 4

$6167-4816$

SYSTEK; FILTER;

FILTER SYSTEM, FOR WSCF NORTH LABORATORY HVAC

STOCK NUMEER $6167-4816-0414$
IL/SC PART DESCRIPTION

QAG; HEPA FILTER CHANGE OUT;

BAG, HEPA FILTER CHAHGE OUT,

POL YVINYLCHLORIDE, 90C $\times 1081$,

PVC-Y-TSP-8.90C X 108, FOR HEPA FILTER REMOVAL/REPLACEMEMT ON CHARCOAL SERVICE CORP. F-SERIES BAG-IN/BAG-DUT FIITER

HOUSINGS.

SSC/AD: GS/Q

CLAUSE: 834

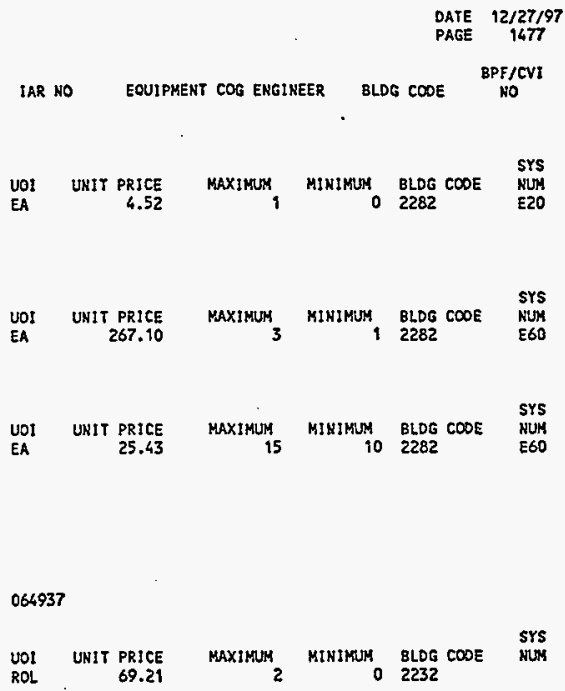

SYS NUS 
cs.001

JCK NUMBER

OESCRjPTIOH

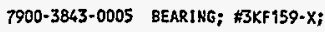

7900-3885-6401 STATION; COHPRESSED AIR; COMPRESSED AIR STATIOH PER ATTACHED SPECIFICATION WHC-5-0235, REVISION 1 , DATED JAN. 26, 1994

WITH UPGRADED AIR FILTRATION

7900-3900-6201 GAUGE;

GAUGE LEVEL, SERVO TYPE, EKRAF-NONIUS MOOEL \#854 ATS MEETING OR EXCEEDJNG THE ATTACHED REOUIREMENTS DATED $12 / 20 / 93$.

GAUGE TO INCLUDE THE FOLLOUING DPTION: $1 / 4$ INCH NPT TAP AND PLUG IN DRUM HOUSING FOR PURGE CONHECTION.

7900-3964-8301 RECEPTACLE; GFCI HUBBELL; GF53621;

7900-3964-8302 SWITCH;

7900-3964-8303 KIT; NEUTRAL; DTHOONK

7900-3964-8304 KIT; GROUND; DS468GK

7900-3964-8305 FUSE; GOULD; TRSSR

0.3964-8306

SWITCK; SAFETY; SOUARE-D H3630S

7900-3964-8307 KIT; NEUTRAL; SQUARE D HIOOSN

7900-3964-8308 KIT; GROUND, SQUARE D PKOGTA-2;

7900-3964-8309 SWITCK; SAFTY SOUARE-D H3610S;

7900-3964-8310 KIT; GROUND SOUARE D PK3GTA-1;

7900-3964-8319 20NE; MIMI-PONER, SQUARE-D MPZ10S40F;
HANFORD INVENTORY PROGRAY CONVENIENCE STORAGE CATALOG

$$
\begin{aligned}
& \text { IL/ } \\
& \text { SC UNIT PRICE }
\end{aligned}
$$$$
\text { 207.00 EBP-E01-B00 }
$$$$
1,536.67 \text { EY4-RO4-GOO }
$$$$
4
$$

3

3

$6,058.00$ ECP-EOS-EDO

18.36 EBP-DOY-600

$1,995.00 \mathrm{Esp} \cdot 001 \cdot 800$

68.06 EBP-DOI-BDO

58.67 EBP-D01-BOO

3.12 EBP-DO1-BOO

1,157.00 EBP-DOt-BOO

23.15 EBP-DO1-B0O

$\$ 1.62$ EBP-DO1-BOO

$530.00 E B P-D 01-B 00$

2.42 EBP-DOt-B00

771.00 EBP-G15-B00

HAND UOI STORAGE REQUESTOR

o ea kelly, diane C

I LOT WALLREN, CARL B

2 EA BARHES, GEOFFREY A

61 PERALES, GeRALD D

I PERALES, GERALD D

I 1 perales, gerald D

i PERALEs, gerald D

31 PERALES, GERALD D

1 t PERALES, GERALD D

i perales, geralo o

1 ea perales, geralo o

i EA - PERALES, GERALD D

11 PERALES, GERALD D

3 I PERALES, GERALD D 
CS+001

- OCK NUMEER

DESCRIPTIOH

KANFORD INVENTORY PROGRAM CONVENIENCE STORAGE CATALOG

9900-4131-0005 ASSEMBLY; GRAPPLER; (H-2-79378) AIR LANCE REMOVAL EQUIPMENT 4 (LOT A 1 OF 2)

$9900-4931-0006$ RETRACTOR; ASSEMBLY; (H-2-79412) AIR LANCE REMOVAL EOUTPTMENT 4

9900-4131-0007 ASSEMBLY; PULLER ASSEHBLY

- (HIT OHLY) (H-2-79376) USE M.1.T. REMOVAL EQUIPMENT WITH 1 EA. 20 ' LENGTH HYORAULIC HOSE AIR LANCE REMOVAL EOUIPHENT

9900-4131-1001 CONPRESSOR; RECIPROCAIING; NON-LUBRICATED INSTRUNENT AIR, 15HP, IHGERSOLL RAND MODEL TOT3NLV, 50 CFM, SERIAL NO. $30 T 742595$

9900-4131-2001 GAUGE; RADAR LEVEL; ENRAF NORIUS (EN) SERIES NO.872 3 PIECES I GAUGE 1 STAND I CONTROLLER

9900-4132-1001 FILTER; CYLINDRICAL, DONALDSON CO. P/N P19.4412. $(6167 \cdot 5160-1700)$

9900-4132-1002 FILTER; BEPR; CYLINDRICAL, DONALDSON CO. P/H P19.4414 $(6167-5160-1710)$

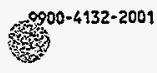

COMPACTOR;

COHPACYOR, COHANCHE CUBIC YARD (COHBINED 4 AND AIR), PART NO. CCYC-HJ/A, MANLFACTURED BY STRAMRITE.

9900-4132-2002 PLATE; REPLACEMENT PLATE, ROND (FOR USE WITH 4 55 GALLON DRM.) PART NO. RP-55

$9900-4132-2003$ COVER;

PROTECIIVE PLATE (FOR USE WITH REPLACEMEMT PLATE). PART NO. PP-C-2T

9900-4132-3001 MOTOR; ELECTRIC, G.E. MOSEL SKS254BD5A; 15 HP 37.4/18.7 AMPS FRAME 254T TEFC CONTINUDUS DUTY

9900-4132-3002 TUBING; DEKORON D SPEC. 1201-44004;
IL' STORAGE BAL ON

LOC

$4.00=00 X-103=000$

$1.00 E 0 X \cdot 1103=000$

1.00 EDX-1303-000 3

$.10 \mathrm{EBP}-\mathrm{EO}-\mathrm{AOO}$ 4

.00 EBP-EO5-A0O

156.00 EBP-B04-COO

$120.00 \mathrm{EBP}-\mathrm{BO}-\mathrm{COO}$

$6,000.00$ EAX-A17-000

110.00 EAX-A17-000

10.00 EAX-A17-000

4

4

$1,000.00$ EBP-BOS-AOO

$1,000.00$ EBP-800-ADO

$1.00 \div 8 p-806-A 00$
DATE $12 / 27 / 97$

PAGE 181

HAND UOI - STORAGE REQUESTOR
IEA. RUST, GLEHN J

I EA RUST, GLENH J

1 EA. RUST, GLENK J

1. EA ZUSKA, KENNETH S

I LOT ZUBKA, KENMETH J

10 EA ZUBKA, KENHETH J

10 EA ZUBKA, KENNETH J

I EA SUITOH, SCOTT C

I EA SUTTOH, SCOTT C

2 EA SUTTOH, SEOTT C

1 EA SPEARS, CATHY $S$

3 EX SPEARS, CATHY $S$ 
CS.001

DESCRIPTION

HANFORD INVEKTORY PROGRAM CONVENIEHCE STORAGE CATALOS

$$
\text { OCK NUMBER }
$$

9900-4150-6019 AIR CONDITIONER; WALL MOUNT, 18,000 BTU'S, 220V, PART \#WAS186L2A

$9900-4150-6020$

ADAPTER;

PLATE CAMERA RISER ADAPTER, BOLTS AND GASKETS, JOB REFERENCE 2H:96.0009, SY103

9900-4150-6021 PAD; COOL;

MEDIA, 20'X36", STOCK $\$ 7150$

JOB RETERENCE $213 \mathrm{H}$

$9900-4150-6022$

ELEMENT:

MICROH FILTER, SCHROEDER K10, JOB REFERENCE $213 \mathrm{H}$

9900-4150-6024 KIT:

END SEAL KIT, CHROMALOX PART HRT-TES

JOB REFERENCE 213H

9900-4950-6027 BELT

$\checkmark$-BELT, A38, JOB REFERENCE 213H

9900-4150-6028 BELT:

V-BELT, B50, JOB REFERENCE $213 \mathrm{H}$

9900-4150-6029 BELT:

V-BELT. 4L380, JO3 REFERENCE 213W

9900-4950-6030 BELT;

$V$-BELT, 4L600, JOS REFERENCE 213Y

\%00-4150-6031 BELT:

$V$-BELT, A38

JOB REFERENCE 213W

$9900-4150-6032$ BELT. $\checkmark$-BELT, 2600. GRTES, JOB REFERENCE $213 \mathrm{H}$

$9900-4150-6033$ MODULE;

TC, UNCALIBRATED TC MOOUEL, PN \#001673-650-502-20, EOUIPMETER JOB REFERENCE $213 \mathrm{H}$

9900-4150-7001 GAUGE; LEVEL: LEVEL GAUGE, EKRAF NONIUS 854 ATG HODEL ? \#UEAZ854K21 F28/LCUS.

$9900-4150-7002$
IL/ STORAGE
SC UNIT PRICE
LOC OH

LOC HANO UOT

1.00 EBP-AO9-AOO

1 EA STARK, KAREN L

1.00 EBP-A08-A00

$I$ EA SIARK, KAREN L

$1.00 \mathrm{EBP}-\mathrm{AOS}-\mathrm{AOO}$

2 ROL STARK, KAREH L

$1.00 \mathrm{EBP}-\mathrm{A12}-\mathrm{B00}$

2 BOX STARK, KAREM L

1.00 EBP-A12-BO0

10 EA STARKX, KAREN L

1.00 EBP-A12-800

3 EA STARK, KAREN L

$\$ .00 \mathrm{EBP}-\mathrm{A} 12-800$

O EA STARK, KAREN L

$9.00 \mathrm{EBP}-\mathrm{A12}-\mathrm{BOO}$

$1.00 \mathrm{EBP}-\mathrm{A} 12+\mathrm{BOO}$

$1.00 \mathrm{EBP}-\mathrm{A} 12-800$

$1.00 \mathrm{EBP}-\mathrm{A} 12-\mathrm{B} 00$

$1.00 \equiv B P-A 12-B 00$

4 EA STARK, KAREN L

.00 EBP-F06-D00 EBP-F07-DOD EBP+F $11-C D O$

16 EA ZUBKA, KENNETH J

.00, EBP- $108-600$

9 EA ZUBKA, KENNETH J 


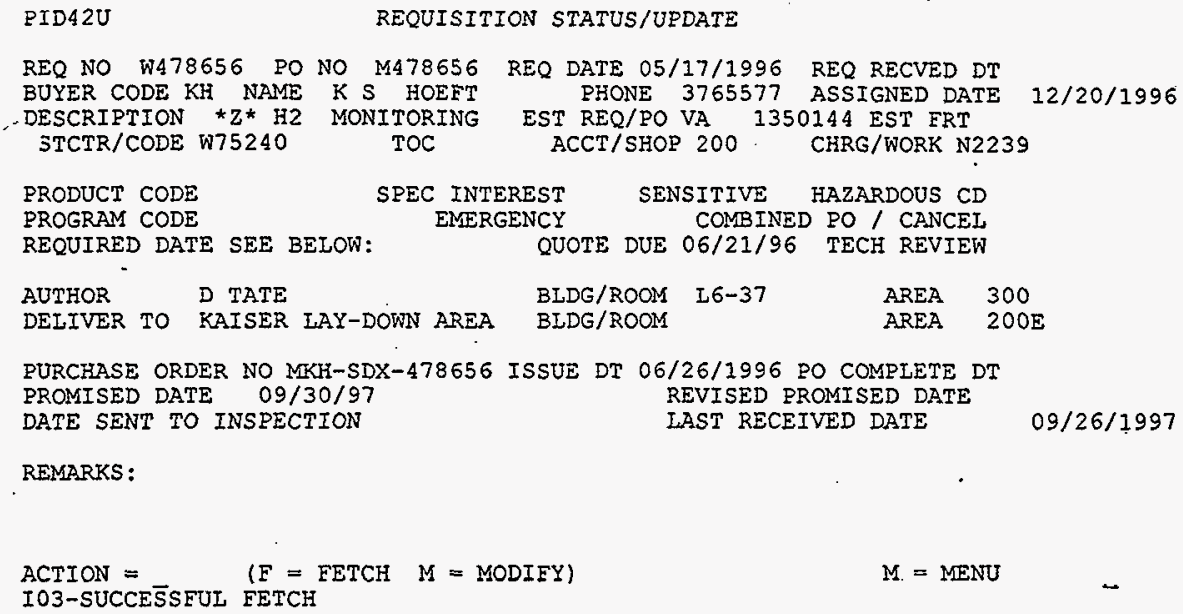


HNF-2404, Rev. 0

PID38U

RMO-125 PURCHASE ORDER RECEIPT STATUS 12/30/1997 09:07:21

PO-NO M478656 BUYER K S HOEFT PO-DT 06/26/1996 PROMISED DT 09/30/97 SHIP-AUTH 10 PO-VAL 1350144.13

ELVR TO KAISER LAY-DOWN AREA

ITEM DESCRIPTION

H7-08 VENDOR 61754 COMPLETE DT MID COLUMBIA ENGINEERING INC VARIANCE 10 RR IOC 12 200E LST RR 06/16/1997 DOC-NO DATE QTY-RCVD INV-QTY-RCVD CHKR REASON CSTD-DT

001 S HYDROGEN MONITORING SYSTEM EA

$$
092796 \quad 34380.00
$$

$002 S$ E+ HYDROGEN MONITORING SYST EA IN 082896

IN 112196

IN $1089-1$

IN $112196 \mathrm{~A}$

IN 112196

IN 1096-4

$\begin{array}{lr}083096 & 288534.20 \\ 112196 & 30000.00 \\ 012897 & 66467.12 \\ 112196 & 10000.00 \\ 112196 & -30000.00 \\ 021197 & 170617.68\end{array}$

003 S E+ HYDROGEN MONITORING SYST EA IN 102396 MORE RECORDS TO DISPLAY
$34380.00 \quad 34380.00$

$535619.00 \quad 535619.00$ 101496961014183116
306068.00306016 .00 151503.66

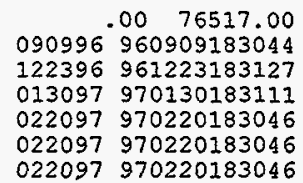

$52.00 \quad 76517.00$ 112696961126183111 $M=M E N U$ 


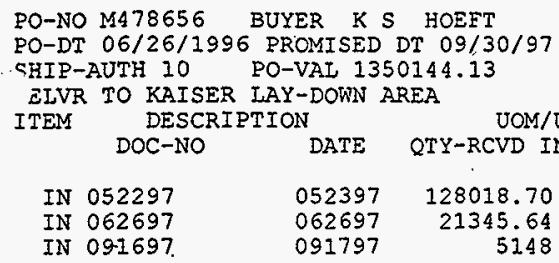

$004 \mathrm{~S}$ E. HYDROGEN MONITORING SYSTE EA IN $121896 \quad 122096 \quad 50150.00$ IN $1096-4 \quad 021197 \quad 2850.00$

H7-08 VENDOR 61754 COMPLETE DT MID COLUMBIA ENGINEERING INC VARIANCE 10 RR LOC 12 200E IST RR 06/16/1997

JOM/UOI QTY-ORD QTY-RCVD QTY-DUE UNIT-PRICE $\begin{array}{lrr}\text { IN } 052297 & 052397 & 128018.70 \\ \text { IN } 062697 & 062697 & 21345.64 \\ \text { IN } 091697 & 091797 & 5148\end{array}$ QTY-RCVD CHKR REASON CSTD-DT $\begin{array}{cccc}005 \mathrm{~S} E & \mathrm{E} \text { HYDROGEN MONITORING SYSTE EA } & 265000.00 & 265000.00 \\ \text { IN } 102396 & 102896 & 120496.34 & \end{array}$

IN 1835

IN 040897 $031497 \quad 115716.36$ $040997 \quad 28787.30$
060697970606185524 071597970715183037 092697970926184633

$53000.00 \quad 53000.00$ $.00 \quad 53000.00$ 022097970220183046 $.00 \quad 53000.00$ 112696961126183111 032697970326183123 042397970423183108

M=MENU

MORE RECORDS TO DISPLAY

$$
\mathrm{F} 7=\mathrm{PAGE}-\mathrm{UP} \quad \mathrm{F} 8=\mathrm{PAGE}-\mathrm{DOWN}
$$


PO-NO M478656 BUYER K S HOEFT
PO-DT O6/26/1996 PROMISED DT O9/30/97
SHIP-AUTH $10 \quad$ PO-VAL 1350144.13 ELVR TO KAISER LAY-DOWN AREA ITEM DESCRIPTION DOC-NO DATE
H7-08 VENDOR 61754 COMPLETE DT

MID COLUMBIA ENGINEERING INC VARIANCE 10 RR LOC 12 2OOE

LST RR 06/16/1997

UOM/UOI QTY-ORD QTY-RCVD QTY-DUE UNIT-PRICE QTY-RCVD INV-QTY-RCVD CHKR REASON CSTD-DT
$006 \mathrm{~S}$ CANCEI

007 S TECHINICAI ASSISTANCE AND TR EA

$008 \mathrm{~S}$ INCENTIVE PAYMENT TO ACCELE IOT $\begin{array}{lll}\text { IN } 112196 \mathrm{~A} & 112196 \quad 20000.00\end{array}$

009 S SEMS-E/E+ ANCILLARY EQUIPME IOT IN 120696

IN 052297

IN 062697

IN 120696

IN 120696RET

MORE RECORDS TO
$121096 \quad 57441.00$

$052397 \quad 26097.33$

$062697 \quad 263.61$

$121096-8616.50$

$071897 \quad 8616.50$

DISPLAY $\begin{array}{llll}.00 & .00 & .00 & .00 \\ .00 & .00 & .00 & .00\end{array}$

$20000.00 \quad 20000.00$

.0020000 .00 022097970220183046

$83801.94 \quad 83801.94$

$.00 \quad 83801.94$

010997970109230310

060697970606185524

071597970715183037

072297970722183056

072297970722183056

$M=$ MENU 


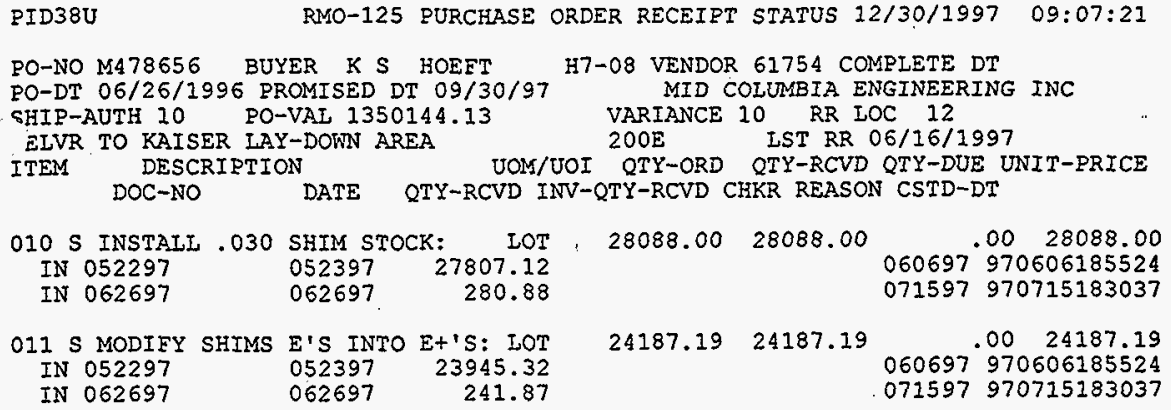

END OF DISPLAY

$$
F 7=\text { PAGE-UP } \quad F 8=P A G E-D O W N
$$


Appendix $\mathrm{E}$

SHIMS Credit Store Order

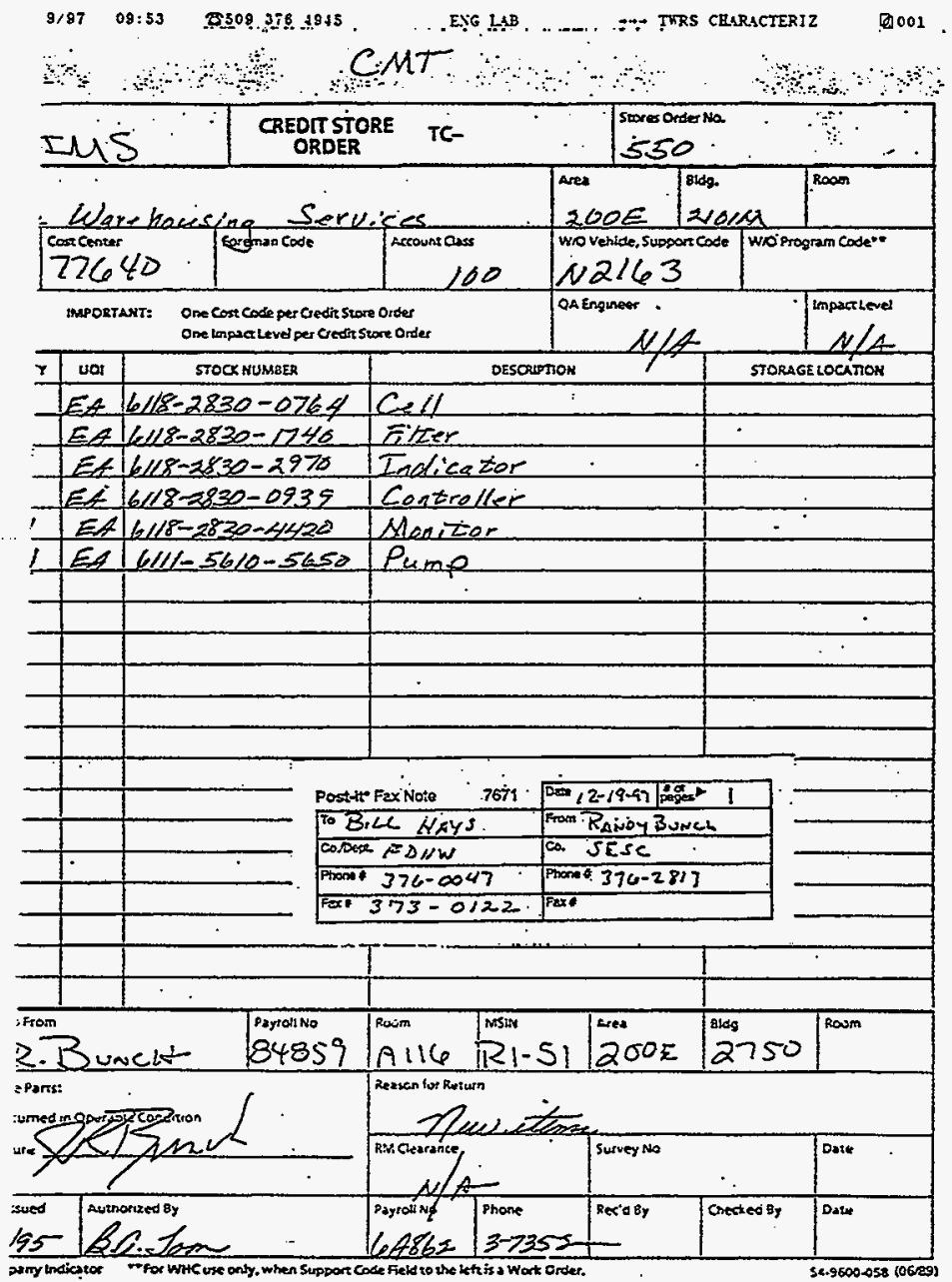


Appendix $\mathrm{F}$

Hanford Inventory Program

Spare Parts by Building Code

Building Code 2420

\begin{tabular}{|c|c|}
\hline$S P-005$ & $\begin{array}{l}\text { HANFORO 1HVENTORY PRC } \\
\text { SPARE PARTS BY BLDG }\end{array}$ \\
\hline $\begin{array}{l}\text { BLDG CODE } 2420 \\
\text { COGNIZANT ENGINEER } \\
?\end{array}$ & $\begin{array}{l}\text { EDDEN, MORMAN B } \\
\text { MFG: KUHKLE P/N: 6010DD01 CLAUSE: } 924\end{array}$ \\
\hline $\begin{array}{l}\text { STOCK MUABER BASIC } \\
6167-2855\end{array}$ & 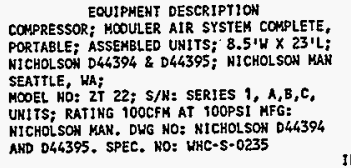 \\
\hline $\begin{array}{r}\text { STOCK MUMBER } \\
6167-2855-0460\end{array}$ & $\begin{array}{l}\text { PART DESERIPTION } \\
\text { BELT; V, DRIVE; } \\
\text { CFOA EOUIPMENT PIECE \#SA-F-6001 } 3000 \\
\text { SCFM DAYTON BLOWERS MFG: DAYCO P/N: A-68 } \\
\text { CLAUSE: } 924\end{array}$ \\
\hline $\begin{array}{r}\text { STOCK NUNBER } \\
6167-2855-1720\end{array}$ & $\begin{array}{l}\text { PART DESCRIPTION } \\
\text { FILTER; PIEATED; } 14 \times 20 X 9 \\
\text { OUR E.P. HSA-FLI-6007 HOD AIR SUPPLY } \\
\text { FILIER3 MFG: PUROLATOR P/N: HE } 404009 \\
\text { CLAUSE: } 924\end{array}$ \\
\hline $\begin{array}{r}\text { STOCK MUMBER } \\
6167-2855-1722\end{array}$ & $\begin{array}{l}\text { PART DESCRIPTION } \\
\text { FILTER; MULTI POCKET TYPE; } 24 \times 24 \times 19 \\
\text { OR E.P. ISA-FLT-6002 COMPRESSOR CABINET } \\
\text { COOLING FAL BAG FILTER MFG: PUROLATOR } \\
\text { P/N: SP } 40 P 64419 \text { CLAUSE: } 924\end{array}$ \\
\hline $\begin{array}{r}\text { STOCK MMABER } \\
6167-2855-1724\end{array}$ & $\begin{array}{l}\text { PARI DESCRIPTIOH } \\
\text { FILTER; PRE; 24X24X4 } \\
\text { OUR E.P. HSA-FLT+600I CONPRESSOR CABINET } \\
\text { COOLIKG FAN PRE-FILTER. MFG: PUROLATOR } \\
\text { P/N: HK } 404404 \text { CLAUSE: } 924\end{array}$ \\
\hline $\begin{array}{l}\text { STOCK MHBER BASIC } \\
6167-4776\end{array}$ & 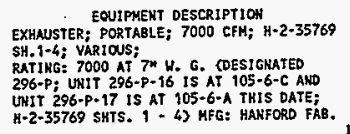 \\
\hline $\begin{array}{r}\text { STOCK NUHABER } \\
6167-4776-0292\end{array}$ & $\begin{array}{l}\text { PART DESCRIPIION } \\
\text { ASSEMBLY; CENTRIFUGA FAH; 7000 CFH } \\
\text { MOOEL: 2OAF; RATIRG 7000 CFH AT 7H NG; } \\
\text { TYPICAL S/N 72-19512-0 (PACE 2OAF CEKT. }\end{array}$ \\
\hline
\end{tabular}
IL MAX MIN BAL ON STORAGE SYS SC OTY OTY HAND UOI UKIT PRICE BELT: $Y$ DRIVE;

\section{AME}

\begin{tabular}{|c|c|c|c|c|c|}
\hline $\begin{array}{l}\operatorname{MAX}_{\text {OTY }} \\
{ }_{6}\end{array}$ & $\begin{array}{l}\text { KLH } \\
\text { OTY. } \\
2\end{array}$ & $\begin{array}{c}\text { BAL ON } \\
\text { HAND } \\
6\end{array}$ & yot & $\begin{array}{l}\text { UNIT PRICE } \\
\$ 9.70\end{array}$ & $\begin{array}{l}\text { STORAGE } \\
\text { LOCATION } \\
\text { ECP-L12-BOO }\end{array}$ \\
\hline
\end{tabular}

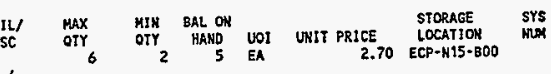

FILTER; PRE; $24 \times 24 \times 4$ COMPESSOR CABINET 4

OUR E.P. HSA-FLTGOOTER. MFG: PUROLATOR

P/N: $H$ HK 404404 CLAUSE: 924

EXHAUSTER; PORTABLE; $7000 \mathrm{CFM}$; $\mathrm{H-2-35769}$
SH. $\{-4 ;$ VARIOUS;

RAIIRG: 7000 AT Th W. O. CE 105-6-C AND

UHIT 296-P.17 IS AT 105.6-A THIS DATE;

H-2-35769 SHTS. 1 * 4) MFG: HAKFORD FAB.

AOH

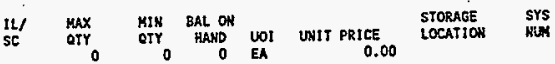


HNF-2404, Rev. 0

sp-005

BLOG COOE 2420 COGNIZANT EKGINEER EDDEN, NORMAK B

ANFORD INVENTORY PROGRA

SPARE PARTS EY BLDG COOE

AHT OL 2500

RPH. 15KP OPEN DRIP PROOF. $1800 \mathrm{RPH}$

460/3/60. FIXED PITCH BELT DR. MAHUAL

INLET VAIH.

*ACATALOS OKLY - USE 6167-4012-1600** NOT FUND IN INUENTCRY

STOCK NLMBER $6167 \cdot 4776-0901$

STOCX MUABER $6167+4776 \cdot 0914$

STOCK NUMBER $6967-4776-4926$

STOCX MUABER $6167-4776-4276$

STOCK RUABER $6167-4776-4410$

STOCK MUMBER $6167-4776-6003$

STOCX MUMBER $6167-4776-7336$

STOCX MUMBER $6167-4776-7338$

$$
\begin{aligned}
& \text { PART DESCRIPIION } \\
& 2018
\end{aligned}
$$

PART DESCRIPTIOI

HOTOR: ELECTRJC; 15 HP

MDOEL NO: TYPE SC; RATING: 15 HP AT 1750

RPH $230 / 4603 \mathrm{PH} 40 / 20 \mathrm{~A} 1.15$ SER. FAC.

CLASS B IHS. 254-T FR. COPEN ORIP PROF

MOTOR 40 DEG. C AMB. TEMP. MEMA DES. BI

*catalog ONLY - USE 6117-4055-4400*a

$$
\begin{gathered}
\text { POY8 } \\
\text { PART DESCRIPTION } \\
\text { RELAY; LINE VOLT; 110/120V } \\
\text { "*CATALOG OHLY - USE 6117-6039-5950** } \\
\text { 2C18 }
\end{gathered}
$$$$
\text { PART DESCRIPTION }
$$

SWITCH; PILOT LIGH, PUSH TO TEST: * CAIALOG ONLY - USE 6117-7691-7301**

PART DESCRIPTION

PART DESCRIPTION
SWITCH; PUSH BUTTON; HEAW DUTY GOOAC wax

* catalog only - USE 6117-7691-7300**

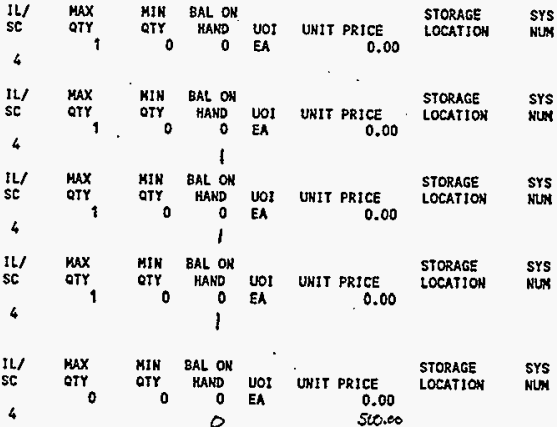

$$
\begin{aligned}
& \begin{array}{llll}
\text { IL/ WAX MIK BAL ON } & & \text { STORAGE } & \text { SYS } \\
\text { SC OTY OTY HANO WOI UNIT PRICE, LOCATION WUM }
\end{array} \\
& \begin{array}{rrrrr}
4 & 1 & 0 & 0 & \text { ER }
\end{array}
\end{aligned}
$$

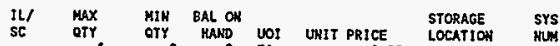


HNF-2404, Rev. 0

\begin{tabular}{|c|c|c|c|c|c|c|c|c|c|}
\hline$s p-005$ & $\begin{array}{l}\text { HAMFORD INVENTORY PR } \\
\text { SPARE PARTS BY BLDG }\end{array}$ & $\begin{array}{l}\text { OOGRAM } \\
\text { CODE }\end{array}$ & & & & & & $\begin{array}{l}\text { DATE } \\
\text { PAGE }\end{array}$ & $\underset{1870}{2 / 21 / 88}$ \\
\hline $\begin{array}{l}\text { BLDG CODE } 2420 \\
\text { COGNIZAHT EKGINEER } \\
\text { STOCX NLHABER } \\
6967-4776-7530\end{array}$ & $\begin{array}{l}\text { EDDEN, NOAHAN B } \\
\text { PART DESCRIPTION } \\
\text { THERNOSTAT; AMP } 125.250 \text { VAC } \\
\text { "CATALOG OHLY - USE 6117-8828-7525** }\end{array}$ & $\begin{array}{l}\text { ILI } \\
\text { SC } \\
4\end{array}$ & $\begin{array}{l}\text { MAX } \\
\text { orr } \\
1\end{array}$ & $\operatorname{PIY}_{0}^{\text {MIN }}$ & $\begin{array}{c}\text { BAL ON } \\
\text { HAND } \\
0 \\
1\end{array}$ & Uot & $\begin{array}{l}\text { UXIT PRICE } \\
0.00\end{array}$ & $\begin{array}{l}\text { STORAGE } \\
\text { LOCATION }\end{array}$ & $\begin{array}{l}\text { SYS } \\
\text { NIS }\end{array}$ \\
\hline $\begin{array}{r}\text { STOCK MUNBER } \\
6167-4776-7570\end{array}$ & $\begin{array}{l}\text { PART DESCRIPTION } \\
\text { TIMER; MOTOR DRIVEF; } 60 . \text { TIME RANGE S.5 } \\
\text { MIN } \\
\text { "*CATALOS ONLY - USE } 6117-8505-7550 * * \\
20,8\end{array}$ & $\begin{array}{l}\text { JW/ } \\
\text { sc } \\
4\end{array}$ & $\max _{1}^{\max }$ & $\operatorname{MIY~}_{0}^{\text {OIY }}$ & $\begin{array}{c}\text { BAL OH } \\
\text { HAHO } \\
0 \\
1\end{array}$ & $\begin{array}{l}\text { WOI } \\
\text { EA }\end{array}$ & $\begin{array}{l}\text { UNIT PRICE } \\
0.00\end{array}$ & $\begin{array}{l}\text { STORAGE } \\
\text { LOCATIOM }\end{array}$ & $\begin{array}{l}\text { SYS } \\
\text { NUW }\end{array}$ \\
\hline $\begin{array}{r}\text { STOCK NUNBER } \\
6167-4776-7700\end{array}$ & $\begin{array}{c}\text { PART DESCRIPTION } \\
\text { TRANSFORMER; CUSRENT; SO/5 ANP } \\
\text { * CATALOG ONLY - USE 6197-8930-7650** }\end{array}$ & $\begin{array}{l}14 / \\
\text { sc } \\
4\end{array}$ & $\operatorname{MAX}_{1}^{\operatorname{Max}}$ & $\underset{0}{\text { MIN }}$ & $\begin{array}{c}\text { BAL ON } \\
\text { HAND } \\
0 \\
1\end{array}$ & $\begin{array}{l}\text { WOI } \\
\text { EA }\end{array}$ & $\begin{array}{l}\text { UNIT PRICE } \\
0.00\end{array}$ & $\begin{array}{l}\text { STORAGE } \\
\text { LOCATION }\end{array}$ & $\begin{array}{l}\text { Sys } \\
\text { MUH }\end{array}$ \\
\hline $\begin{array}{r}\text { SYOCK NLWBER } \\
6167-4776-7702\end{array}$ & $\begin{array}{l}\text { PART DESCRIPIION } \\
\text { TRANSFORER; CURRERT; } 150 / 5 \text { NMP } \\
\text { **CATALOS ONLY - USE } 6117-8930.7651^{* *}\end{array}$ & $\begin{array}{l}11 / 1 \\
\mathrm{sc} \\
4\end{array}$ & $\operatorname{mix}_{1}$ & $\underset{0}{\operatorname{MIN}}$ QTY & $\begin{array}{c}\text { BAL ON } \\
\text { HAND } \\
0 \\
1\end{array}$ & $\begin{array}{l}\text { vol } \\
\varepsilon A\end{array}$ & $\begin{array}{l}\text { UNIT PRICE } \\
0.00\end{array}$ & $\begin{array}{l}\text { STORAGE } \\
\text { LOCATION }\end{array}$ & $\begin{array}{l}\text { SYS } \\
\text { MLM }\end{array}$ \\
\hline $\begin{array}{r}\text { STOCK MUNBER } \\
6167-4776-7704\end{array}$ & $\begin{array}{l}\text { PART DESCRIPTION } \\
\text { TRAHSFORHER; INDOOR/OUTDOOR; IDKVA } \\
\text { **CATALOO OHLY - USE } 6117-8945-7650 * * \\
2018\end{array}$ & $\begin{array}{l}11 / \\
56 \\
4\end{array}$ & $\begin{array}{l}\text { MAX } \\
\text { OTY }\end{array}$ & $\operatorname{MTY}_{0}^{\operatorname{MIN}}$ & $\begin{array}{c}\text { BAL OH } \\
\text { BAND } \\
0 \\
1\end{array}$ & $\begin{array}{l}\text { Wot } \\
\text { EA }\end{array}$ & $\begin{array}{l}\text { UNIT PRICE } \\
0.00\end{array}$ & $\begin{array}{l}\text { STORAGE } \\
\text { LOCATIOH }\end{array}$ & $\begin{array}{l}\text { SYS } \\
\text { NUY }\end{array}$ \\
\hline
\end{tabular}




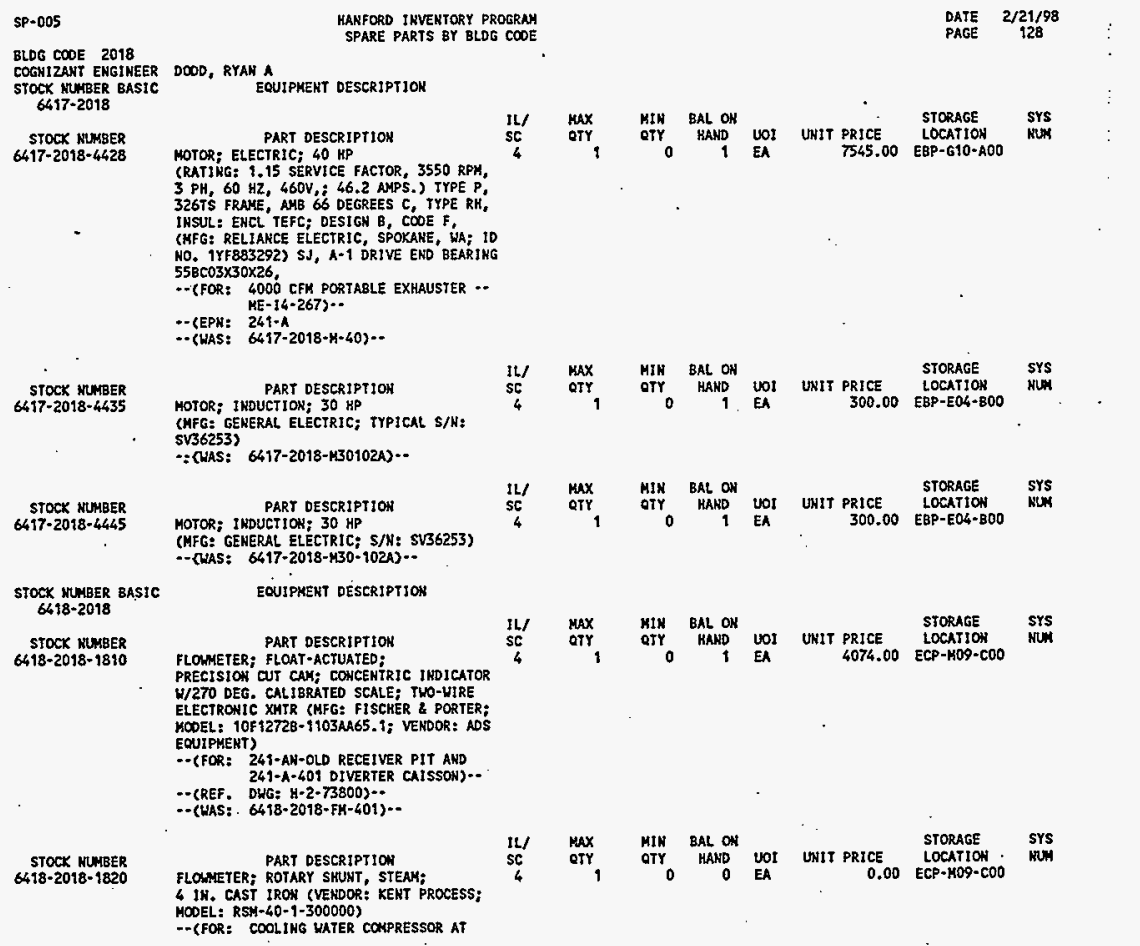




\begin{tabular}{|c|c|c|c|c|c|}
\hline \multicolumn{6}{|c|}{ DISTRIBUTION SHEET } \\
\hline \multirow{2}{*}{$\begin{array}{l}\text { To } \\
\text { Distribution }\end{array}$} & \multirow{2}{*}{$\begin{array}{l}\text { From } \\
\text { W. H. Hays }\end{array}$} & & & \multicolumn{2}{|l|}{ Page 1 of 1} \\
\hline & & & & \multicolumn{2}{|c|}{ Date $3 / 12 / 98$} \\
\hline \multirow{2}{*}{\multicolumn{4}{|c|}{$\begin{array}{l}\text { Project Title/Work Order } \\
\text { Project W-320 241-C-106 Waste Retrieval Spare Parts List }\end{array}$}} & \multirow{2}{*}{\multicolumn{2}{|c|}{$\begin{array}{l}\text { EDT No. } 603743 \\
\text { ECN No. N/A }\end{array}$}} \\
\hline & & & & & \\
\hline Name & MSIN & $\begin{array}{l}\text { Text } \\
\text { With All } \\
\text { Attach. }\end{array}$ & $\begin{array}{l}\text { Text } \\
\text { Only }\end{array}$ & $\begin{array}{l}\text { Attach./ } \\
\text { Appendix } \\
\text { Only }\end{array}$ & $\begin{array}{c}\text { EDT/ECN } \\
\text { Only }\end{array}$ \\
\hline $\begin{array}{l}\text { K. J. Anderson } \\
\text { J. E. Andrews } \\
\text { D. G. Baide } \\
\text { J. W. Bailey } \\
\text { R. R. Bevins } \\
\text { J. R. Bellomy } \\
\text { T. R. Benegas } \\
\text { D. A. Bragg } \\
\text { G. N. Hanson } \\
\text { W. H. Hays } \\
\text { J. M. Jones } \\
\text { M. A. Lane } \\
\text { J. R. LaPointe } \\
\text { J. W. Lentsch } \\
\text { W. J. Powell } \\
\text { S. W. Shaw } \\
\text { D. B. Smet } \\
\text { G. R. Tardiff }\end{array}$ & $\begin{array}{l}\text { S5-04 } \\
\text { S5-04 } \\
\text { S5-05 } \\
\text { S2-48 } \\
\text { S2-48 } \\
\text { S2-48 } \\
\text { S2-48 } \\
\text { S5-05 } \\
\text { S5-07 } \\
\text { B4-57 } \\
\text { S5-13 } \\
\text { S2-47 } \\
\text { R2-88 } \\
\text { S2-48 } \\
\text { S5-13 } \\
\text { S2-48 } \\
\text { R1-56 } \\
\text { S5-05 }\end{array}$ & $\begin{array}{l}x \\
x \\
x \\
x \\
x \\
x \\
x \\
x \\
x \\
x \\
x \\
x \\
x \\
x \\
x \\
x \\
x \\
x\end{array}$ & & & \\
\hline Central Files & B1 -07 & $x$ & & & \\
\hline
\end{tabular}

